\title{
Biodiversity, ecology, and behavior of the recently discovered insect order Mantophasmatodea
}

\author{
Steffen Roth ${ }^{1 *}$, Jorge Molina ${ }^{2}$ and Reinhard Predel ${ }^{3}$
}

\begin{abstract}
The spectacular discovery of the new insect order Mantophasmatodea in 2002 was immediately followed by detailed studies on morphology and scattered information on different aspects of its behavior and general biology. A distinct feature of these predatory insects is the development of large arolia, which are typically held upright; hence, their common name is heelwalkers. The first mantophasmatodean species were described based on two museum specimens originally collected in Tanzania and Namibia. To date, these insects have been observed at surprising levels of diversity and abundance in Namibia and South Africa. For our studies on the phylogenetic relationships within Mantophasmatodea, we collected and analyzed numerous populations that belong to all known mantophasmatodean lineages, including East African populations. These collections not only provided a comprehensive biogeographical overview but also facilitated a comparative analysis of behavior, which was mainly analyzed under laboratory conditions. Here, we review and discuss the published data, as well as provide additional information on Mantophasmatodea distribution, evolutionary lineages, morphology, and biology, with a specific focus on reproductive biology.
\end{abstract}

Keywords: Behavior, Biodiversity, Evolutionary lineages, Life history, Mantophasmatodea, Polyneoptera

\section{Introduction}

The insect order Mantophasmatodea [1,2] was the first new order described since 1914 [3], and several taxa were immediately characterized (e.g. [4-6]). These descriptions were accompanied by a comprehensive description of the morphological features, such as genitalia of both sexes [4], the structure of sperm [7], eggs [8,9], head [10,11], circulatory organs [12], arolium and tarsus [13-16], and antennae $[4,17,18]$, as well as studies on reproductive biology [19], communication [20-22], peptide hormones [23,24], physiology [25], and development $[17,26,27]$. In addition to molecular studies [4,28-31], these studies provided the initial information for reconstructing the Mantophasmatodea phylogeny. Although the interordinal relationship has been disputed with Mantophasmatodea either to Phasmatodea [28] or Grylloblattodea [13,29,31,32], more convincing morphological and also molecular data support Mantophasmatodea as the closest relatives of Grylloblattodea. Considering the short period since Mantophasmatodea

\footnotetext{
* Correspondence: steffen.roth@um.uib.no

'University Museum of Bergen, The Natural History Collections, P.O. Box 7800, N-5020 Bergen, Norway

Full list of author information is available at the end of the article
}

was first described, an extensive body of literature has been generated, which includes behavior and morphology as well as systematic and phylogenetic studies. However, certain general aspects of their biology and ecology are less wellknown. Scattered reports have been published as short notes either in diverse scientific (see references above) or more popular publications (e.g. [33-36]). In this manuscript, we summarize the available information on Mantophasmatodea distribution, ecology, life history, reproduction, and feeding behaviors. Most data are based on our field studies and laboratory observations (see Additional file 1 for methods), for which we sampled specimens from all mantophasmatodean lineages (see [31]) in Southern Africa (Figure 1) and East Africa. In addition to presenting our data, we review the previously available information on ecology and behavior from the scientific literature and other public resources.

\section{Review \\ General remarks and intraordinal relationships}

Mantophasmatodeans superficially resemble mantises and stick insects. Different common names are used in the literature, including gladiator [37,38], rock crawler 


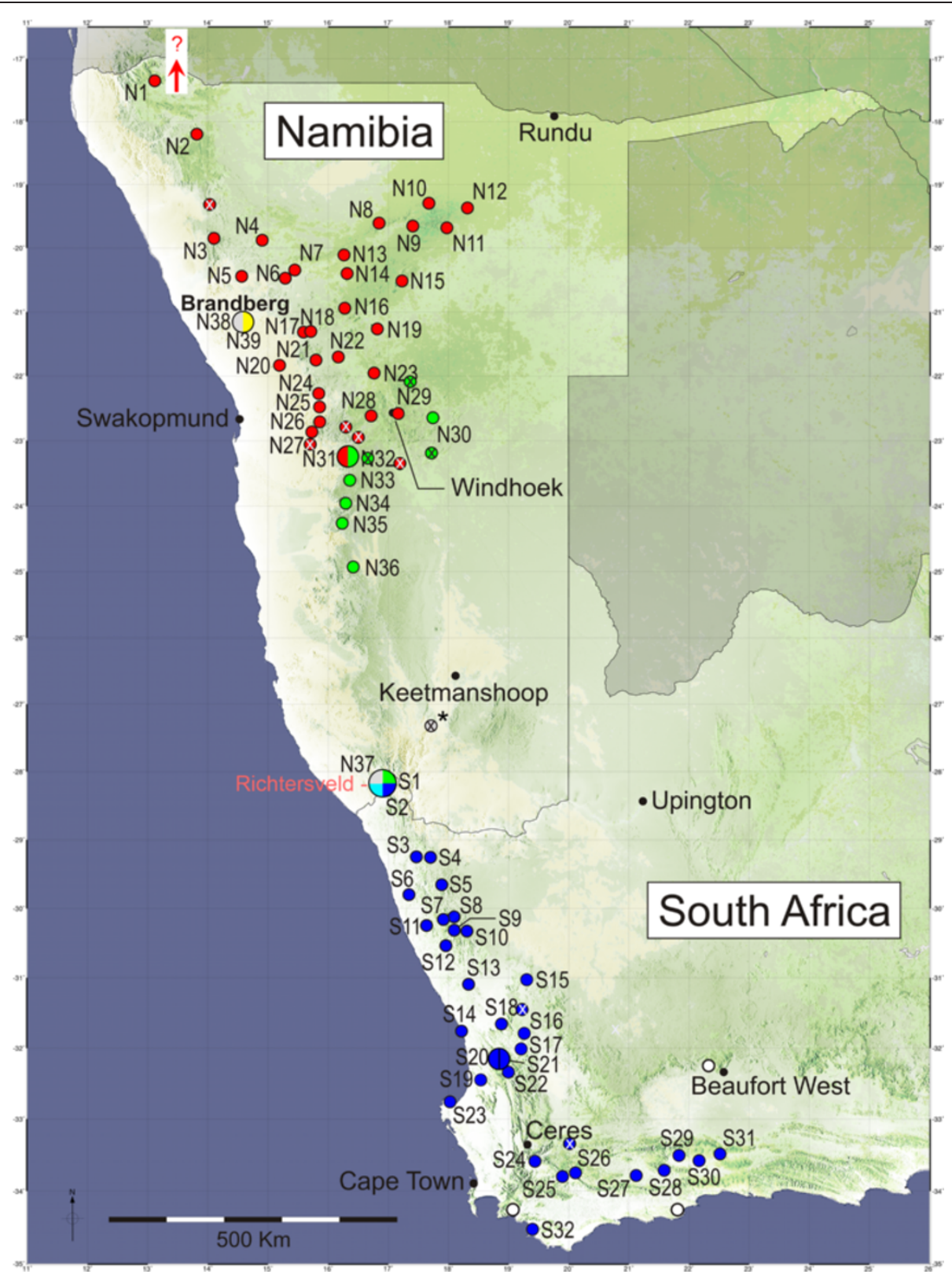

Figure 1 Distribution for Mantophasmatodea in Southern Africa (modified from [31]). The numbered sample spots refer to populations that were analyzed using peptidomics [33]. South African Austrophasmatidae taxa for which the mtDNA sequences were analyzed by [30]) have been collected within the same distributional range in the Western and Northern Cape provinces, except for the populations of Austrophasmatidae marked with white circles (see [30]). The circles marked with an X refer to populations that were recently collected and are not yet included in the phylogenetic studies. The large circles represent areas where several taxa co-occur (genus level). Whereas the respective taxa from Brandberg ( $N$ 39, greenish Pachyphasma; N38 grey brownish Tyrannophasma), and Clanwilliam (S21, greenish Viridiphasma; S20, grey brownish Karoophasma) inhabit different microhabitats, different taxa in the Gamsberg area (N31, greenish Mantophasma; N32, greenish Striatophasma) were occasionally identified in the same bushes. The Richtersveld (arrowhead), which is part of the most northern extension of the winter rainfall region in South Africa, is inhabited by at least four distantly related taxa (Praedatophasma, Namaquaphasma, and two additional undescribed taxa) and, thus, shows exceptionally high diversity at the genus level. A presumptive Praedatophasma population has been reported from the Fish River catchment area (asterisk), which is approximately $100 \mathrm{~km}$ north of the established range (H. Vollbrecht, EduVentures Windhoek; pers. comm.). Red circles, Mantophasma; green circles, Striatophasma; blue circles, Austrophasmatidae sensu [4]); grey circles, Tyrannophasma/Praedatophasma; yellow, Pachyphasma; light blue/light green, undescribed taxa from Richtersveld.

[39], and heelwalker (e.g., [25,30,40,41]). Because 'heelwalker' reflects the typical Mantophasmatodea phenotype, we prefer this designation. Both sexes of all known species, including fossil species $[38,39,42]$ are apterous, which yields a nymph-like appearance. This appearance might be one reason that the Mantophasmatodea specimens were 
not recognized as members of a new insect order for a long time. Mantophasmatodean fossils were discovered in Baltic amber $[38,39,43]$ which indicates a wide distribution in the past. Jurassic fossil findings (165 mya) in China confirm this hypothesis [42]. Currently, Mantophasmatodea have a relict global distribution; most of the 18 described species are concentrated in western Southern Africa areas, except for Tanzaniophasma subsolanum (Tanzaniophasmatidae) in East Africa [1,4,5,30,44,45].

The extant Mantophasmatodea species have been provisionally grouped into three families: Tanzaniophasmatidae (which comprise only the described Tanzanian species of Tanzaniophasma), Austrophasmatidae (9 described species from African genera Namaquaphasma, Karoophasma, Hemilobophasma, Lobatophasma, Austrophasma, Viridiphasma), and the Namibian genus Striatophasma, Mantophasmatidae (8 described species from Namibian genera Tyrannophasma, Praedatophasma, Mantophasma, Sclerophasma, Pachyphasma). Another family-level group has been proposed for accommodating Praedatophasma and Tyrannophasma [30]. In particular, the species identity within the Mantophasmatidae and the placement of Striatophasma in Mantophasmatidae or Austrophasmatidae must be clarified in future studies. A recent phylogenetic analysis of peptide hormone sequences suggests at least eight distinct lineages in Mantophasmatodea, including Tyrannophasma, Praedatophasma, Pachyphasma, Mantophasma (incl. Sclerophasma), Tanzaniophasma, Striatophasma, Austrophasmatidae sensu [4], and an undescribed taxon from the Richtersveld (see [31]). A second undescribed taxon from the Richtersveld (Wipfler \& Predel; in prep.) may link Striatophasma from Namibia and the South African Austrophasmatidae. The monotypic Tyrannophasma, Praedatophasma, and Pachyphasma, as well as the two undescribed taxa from the Richtersveld, are relict taxa with a limited distribution range. In contrast, Mantophasma, Striatophasma, the South African Austrophasmatidae sensu [4], and most likely the poorly known Tanzaniophasma clade are currently successful and widespread taxa. Although a number of Mantophasma species have been described $[1,4,46]$, recent analyses of numerous populations of the genus Mantophasma did not reveal conclusive lineage sorting within this taxon [31]. Even the relationship between the Mantophasma lineage and Sclerophasma paresisense is poorly resolved [16] and requires further analyses to resolve the taxonomical status of this clade. The relationships within the family Austrophasmatidae, which was originally proposed to encompass taxa from the Western and Northern South African Cape Provinces, are well-supported at the genus and species levels. Ambiguities exist on an intrafamilial level for analyses of mitochondrial DNA sequences [30] and peptide hormone sequences [31]. However, these analyses clearly indicate that the family Austrophasmatidae derived from Namibian Mantophasmatodea species. Species from this family may have evolved in a rapidly speciating lineage, which produced a monophyletic group of mostly allopatric species [31].

\section{Distribution patterns and habitats}

All records of extant Mantophasmatodea are from Africa, south of the equator. In East Africa, in the mountainous regions of Malawi (Dedza Mountains, Nyika Plateau), we identified slightly distinguishable populations based on their general appearance and habitus, which most likely belong to the Tanzaniophasma clade (Figure 2). These localities are near the South Tanzanian region, where the only scientifically described (museum) Tanzaniophasma specimen was collected in 1950 (see [1]). In Malawi, the specimens were located in areas characterized by a mixture of grasses and dense bushes (open shrubland and savanna); no specimens were observed in forest biomes. The Mantophasmatodea distribution in East Africa, at least in Malawi, may be negatively affected by extensive vegetation burn off, which is common and widespread in Malawi $[47,48]$. We observed heelwalkers that were

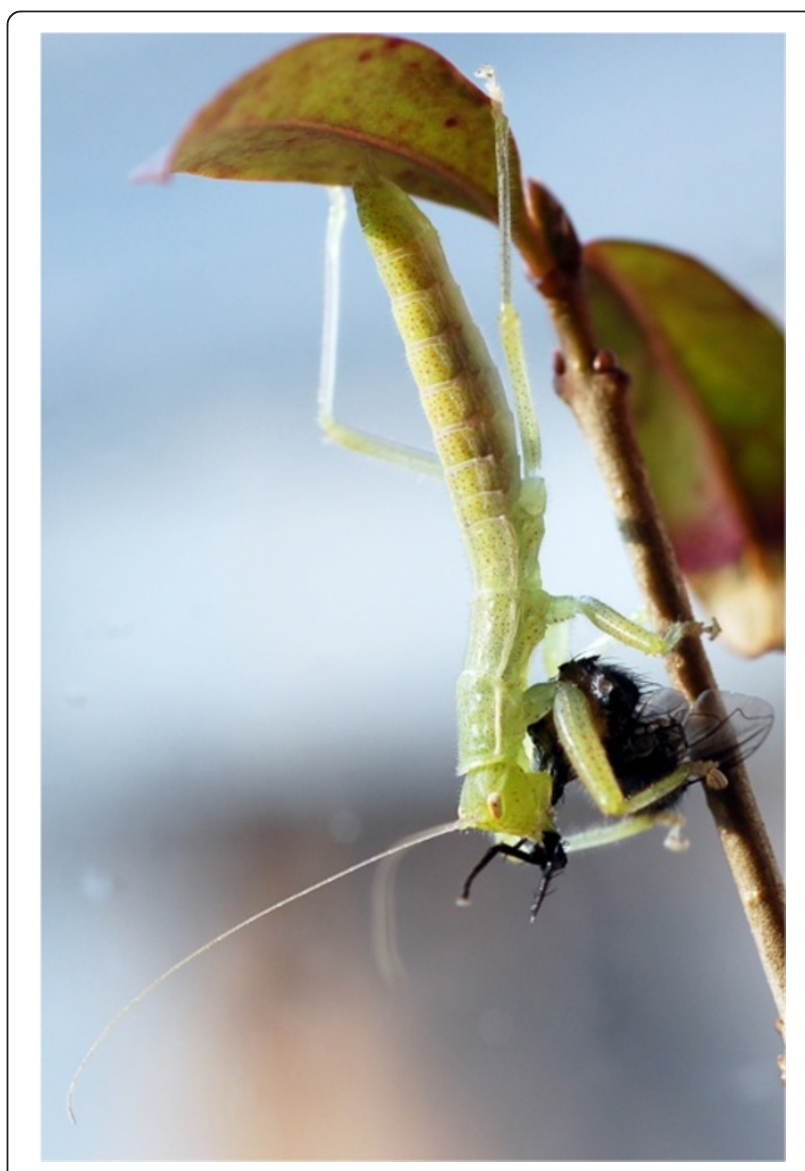

Figure 2 Tanzaniophasma spec. female from the Dedza Mts. (Malawi) with an adult fleshfly as her prey (photo taken in laboratory). 
restricted to dense bushes of different size on rocky hills that were not recently burned (Figures 3 and 4). Hockman et al., [17] noted putative Tanzaniophasma specimens from Cape Maclear, which is on the southern bank of Lake Malawi. In this area we observed nymphs in bush edging an open patch of unused dense shrubland along a creek. The data on Mantophasmatodea distribution in Namibia and South Africa have been discussed in detail by [31]. In short, the southern African distribution appears largely confined to the westernmost Great Escarpment upfoldings; the range of the genus Mantophasma likely extends into southwest Angola (see Figure 1 with multiple new localities). In the Western Cape (South Africa), a few species also inhabit the coastal region, including Sand Fynbos vegetation in the Strandveld, and the Dune Thicket (Fynbos); no specimens have been observed on the Cape Peninsula. The distribution map (Figure 1) suggests that a contemporary dispersal barrier (between 25 and 27 degrees south latitude) exists between the species in the winter rainfall area of Southern Africa and species living in the summer rainfall region of Namibia. A similar distributional discontinuity between Namibia and Namaqualand has been reported for several faunal elements, including other insects, birds, frogs, and mammals [49] (and references therein), and for plant species [50]. Our phylogenetic analyses and their recent distribution suggest that Striatophasma-like species have crossed this region in the past and established a founder population that yielded the present Austrophasmatidae sensu [4] (see [31]).

The spatial patterns of Mantophasmatodea in Southern Africa have been influenced by range fragmentation on a large scale (Namibian versus South African species) and range-edge speciation on a smaller scale. The latter form of speciation was likely driven by geological uplift during the Miocene to Pliocene [51], serial climatic oscillations during the Pleistocene [52], and alternating dry and wet

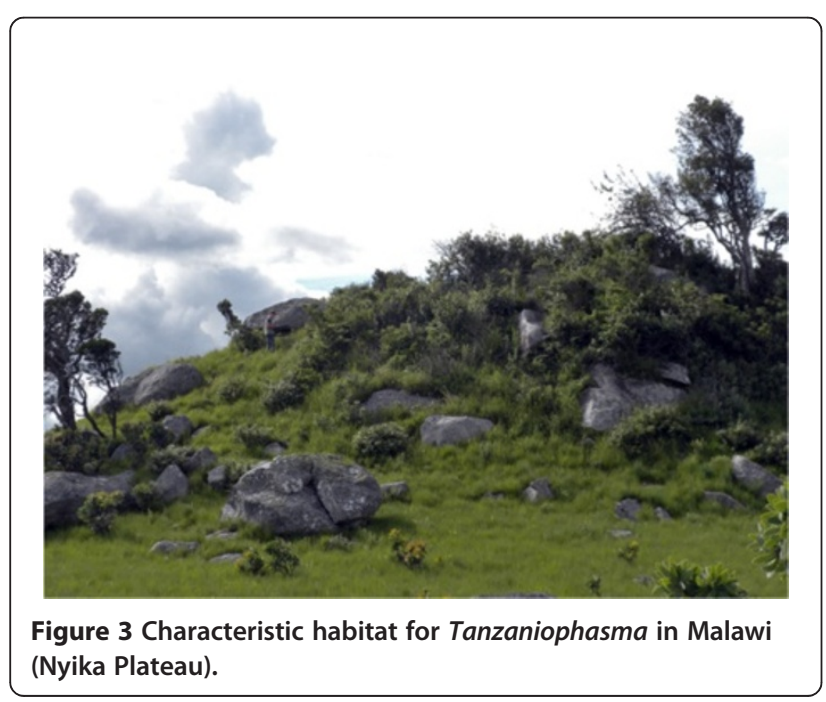

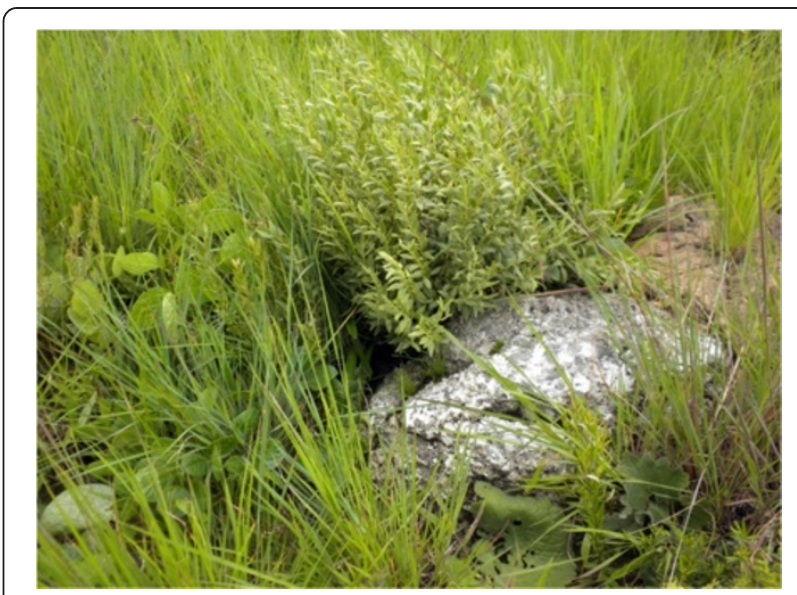

Figure 4 Preferred type of vegetation for Tanzaniophasma at Nyika Plateau (Malawi).

climatic fluctuations. Thus, Mantophasmatodea speciation in Southern Africa was most likely allopatric through vicariance, which has been assumed for other insects [53] and arthropods (Diplopoda; [54]) in the region. Remarkably, the core regions of their recent distribution, such as the Brandberg in Namibia and Succulent Karoo-Fynbos biomes [55-57] typically show exceptional levels of biodiversity and endemism. In these regions, Mantophasmatodea are part of a very unique insect fauna [58,59]. Notably in the context of Mantophasmatodea distribution, no additional mantophasmatodean taxa have been identified within the large Mantophasma distributional range, whereas two distinct monotypic genera are sympatric in different ecological niches on the Brandberg Massif immediately outside the Mantophasma range. Both the genera Tyrannophasma and Pachyphasma appear restricted to the Brandberg Massif and have not been observed in other areas. The Brandberg Massif (the highest mountain in Namibia) has volcanic origins and is isolated from the longitudinal Namibian escarpment (Mantophasma habitat); this isolation has generally ensured that it is a significant relict habitat for numerous endemic organisms (see $[53,55])$. On the Brandberg Massif plateau, Pachyphasma brandbergense was found in the same biotope as Tyrannophasma gladiator. The large and impressive-looking greybrown T. gladiator is mainly found in grass tussocks (see also [33]); however, under dry conditions, nymphs have also been found in dense bushes (altitude 1400-2400 m). The much smaller and greenish $P$. brandbergense is the only mantophasmatodean taxon primarily collected from flowering composite bushes; the ecological relevance of this finding is unknown. The Brandberg Plateau vegetation is characterized by plant species confined to the upper regions of mountains (higher than $1500 \mathrm{~m}$ ); Asteraceae is the most speciose family [60]. The different Mantophasma populations (including Sclerophasma paresisense) inhabit well- 
vegetated mountains in central Namibia up to the Otavi Mountains in the northeast; they also live in mountainous mopane savanna (Kaokoveld) in the northwest. Throughout most of their range, these insects are common in grasses, shrubs, and even trees given sufficient rainfall (see [31]). The density of individuals in a population can be surprisingly high, which is somewhat unexpected for an insect group that has been overlooked for such a long time period. The genus Striatophasma, which was mainly collected south/southeast of the Mantophasma distribution, typically inhabits dry regions with scattered vegetation, and specimens have often been collected from dwarf bushes. In the Gamsberg/Hakos Mountains, Mantophasma and Striatophasma are sympatric. Austrophasmatidae, which live in the winter-rain South African region, were typically found in habitats with sparse to scattered vegetation. Eberhard et al., [44] reported a preference of Viridiphasma clanwilliamense to a small tree (Euclea recemosa), but for most species, we did not observe a preference for hiding on a specific plant species; clearly, Austrophasmatidae select dense bushes or grass tussocks, which provide camouflage and a sufficient prey spectrum. The Kraalbos Galenia africana, a bush that is poisonous to sheep and is common in overgrazed or otherwise disturbed Western/ Northern Cape areas, appears to be particularly attractive to mantophasmatodeans. The occurrence of heelwalkers in strongly disturbed areas suggests that these insects are less sensitive to environmental damage as long as prey is available. At least for the Austrophasma and Hemilobophasma populations, we found that nymphs prefer bushes, whereas adults were typically collected from large grass tussocks. Copulating heelwalkers have regularly been observed in these grasses. Most Austrophasmatidae clades were collected from low altitudes to mountainous locations up to $2000 \mathrm{~m}$, which indicates that different altitudes with changing vegetation types are not effective dispersal barriers for heelwalkers.

Only few Praedatophasma maraisi specimens have been detected in the Richtersveld/Ai-Ais region in the Orange River/Fish River vicinity. The first specimen was collected in 1990 by E. Marais (Windhoek, Namibia) on the Namibian side of the Orange River when it approached a light trap (see [38]); two additional specimens were collected by the authors nearby on the South African Orange River site (Richtersveld). However, this species' distribution appears larger because scholars from Namibia detected a putative Praedatophasma specimen in 2005 in the dry Gaub/Fish River region, which is approximately $90 \mathrm{~km} \mathrm{NW}$ of the confirmed localities $(\mathrm{H}$. Vollbrecht, EduVentures Namibia; pers. communication). It is currently unclear whether these large heelwalkers (Figure 5) hide in vegetation similar to the other mantophasmatodeans. Extensive collection activities in the Richtersveld have yielded three additional and distantly related taxa (see Figure 1) with

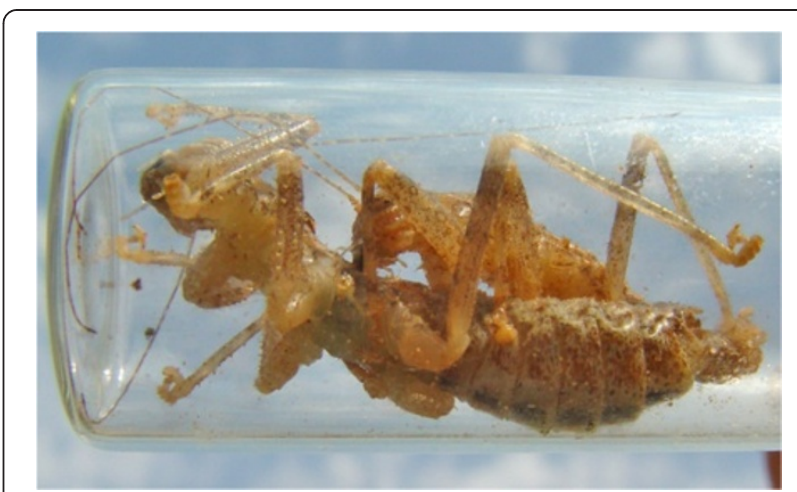

Figure 5 Mating pair of Praedatophasma spec. collected during an EduVentures expedition with scholars from Windhoek in the Fish River catchment region. Photo courtesy of Telané Greyling, Namibia Horse Safari Company, Aus, Namibia.

limited ranges. The succulent Karoo in the Richtersveld/AiAis region, where these four mantophasmatodean taxa have been identified, is only sparsely covered with vegetation and represents the most desert-like habitat in which mantophasmatodeans have been found to date. The Richtersveld is the only recognized arid biodiversity hotspot [61] and is located in the summer- and winter-rain transition zone.

\section{General habits}

Klass et al., [4] Wipfler et al., [45] Wipfler [62] have provided detailed descriptions of mantophasmatodean morphology; here, we focus on certain characteristics related to the ecological and behavioral aspects of their biology. Adults in all Mantophasmatodea species are in the 13$26 \mathrm{~mm}$ range, except for the larger species $P$. maraisi and T. gladiator (up to $35 \mathrm{~mm}$ ). In all species, mature females with developed eggs are substantially larger than males (see below). Both sexes are secondarily wingless and highly flexible along the longitudinal axis. This flexibility enables the species to clean their external genitalia with their mouthparts (Figure 6), but it is also used to attack large prey (Figure 7). The known species' ground color is brownish, grey, or greenish, which indicates camouflage. The Mantophasma, Tanzaniophasma, Pachyphasma, Viridiphasma, Striatophasma, and Austrophasma/Lobatophasma species are typically green; however, the Austrophasma gansbaaiense and Lobatophasma redelinghuysense specimens have been observed with different ground colors (green or brownish) in the same local population, and the Mantophasma specimens have regularly been identified with uniform pale-brown, pale-yellow, or whitish coloring (see also [4,33]). The type of ground color is consistent during nymphal development and cannot be changed, but no detailed information is available regarding the heredity of color frequencies at the population level. Under laboratory conditions without vegetation, many specimens (particularly Mantophasma) became paler, and it is advantageous 


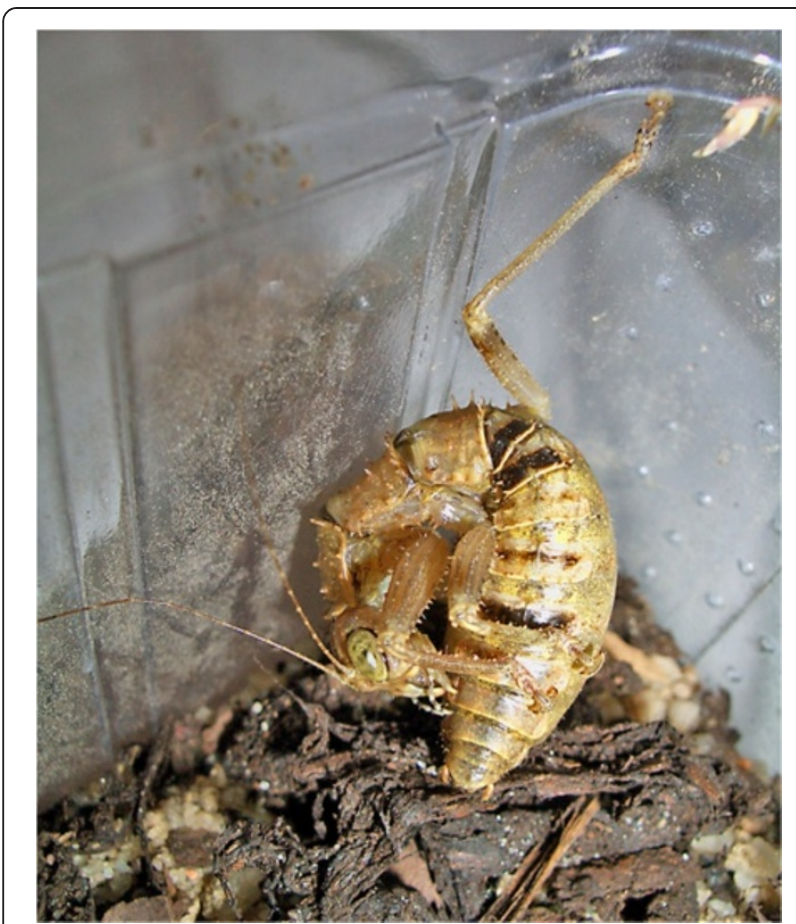

Figure 6 Abdomen grooming by a female T. gladiator (N 38, Brandberg), which shows the flexible body axis. Note the use of a single arolium to adhere the heavy body to the wall of the plastic container (photo taken in the laboratory).

to document the color of specimens in the field. In addition to these general color types, the insect's body might be covered by many spots and median stripes (for a detailed description, see [4]). A number of greenish species exhibit color polymorphism within a population and vary in color

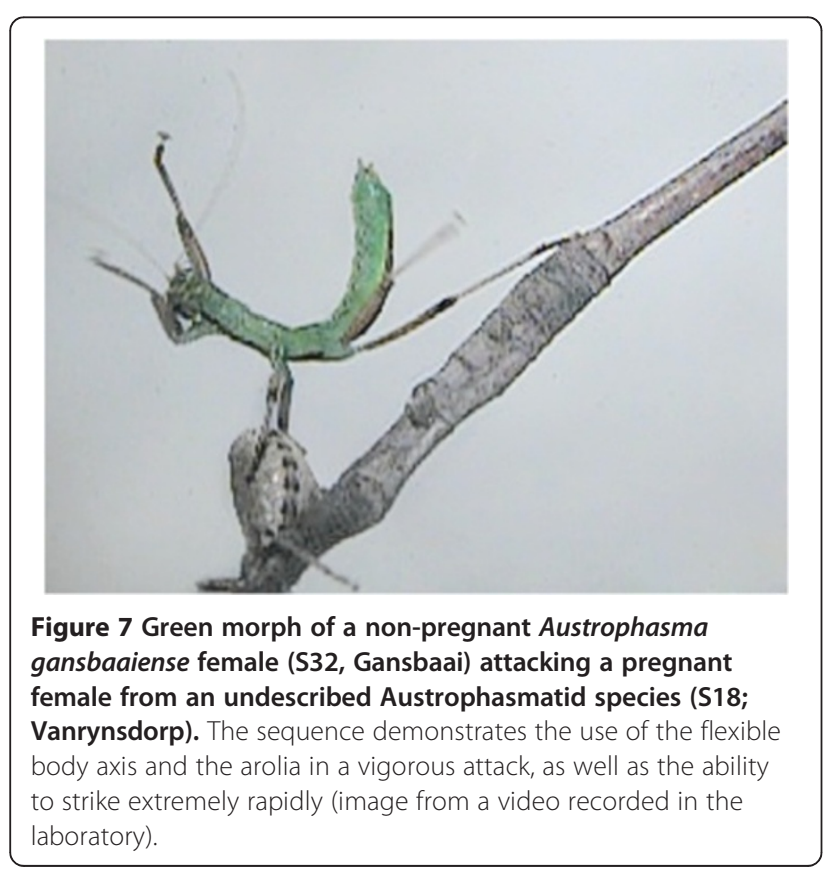

and markings. Brownish dorso-median stripes are typical of a few species (Figure 8). In Striatophasma, only males show the brownish stripe; the coloration is from brown pigments in the dorsal diaphragm. Other species with brownish stripes (e.g., Austrophasma and Lobatophasma) belong to Austrophasmatidae, and both sexes have these stripes. In general, whereas there appears to be no specific link to a particular plant species, for most species, the color matches the habitat structure. Green species occupy the more mesic fynbos vegetation in the Cape region, savanna, and hilly grasslands in Namibia and East Africa, and the grey or drab brown morphs occupy more arid habitats in the succulent Karoo, such as many Austrophasmatidae and P. maraisi. A good example for color adaptation are the Western Cape's green Viridiphasma clanwilliamense and the sympatric Karoophasma biedouwense which were mainly collected from green bushes or low-growing grey and brown karooid shrubs; respectively. In Lobatophasma redelinghuysense, brown and grey striped morphs dominate in dry sandplain fynbos vegetation, while green striped nymphs dominate in more mesic mountain fynbos vegetation [44]. The only greyish/brownish species north of the winter rainfall South African region is T. gladiator, which has a restricted distribution in the Brandberg Massif.

Apart from hunting, when Mantophasmatodea stalk or walk quickly over very short distances to catch their prey, they predominantly sit and hide, and they rarely walk in vegetation. Most species, at least in the family Austrophasmatidae, hide in the centers of bushes or grass tussocks during the day. Night observations verified the presence of Mantophasmatodea in the periphery of bushes or grasses during feeding or mating. Whereas most specimens that were detected with an electric torch tried to hide themselves (Figure 9), one H. montaguense male was observed drumming on a grass stalk (Figure 10). Heelwalkers that were caught and held in hand rarely showed fast escape behaviors. However, in certain cases, we observed a strange "curling" behavior when the specimens were knocked out of a bush. This behavior was particularly conspicuous because, after dropping, Mantophasmatodea typically do not immediately move away. Heelwalkers sometimes jump for small distances, such as a few centimeters (Figure 11; see Additional file 2: Videos 1A, Additional file 3: Video 1B, Additional file 4: Video 1C, Additional file 5: Video 1D), however, we did rarely observe $10 \mathrm{~cm}$ distances as described in [5] for Mantophasma.

Occasionally, Mantophasmatodea actively drop in the vegetation. In most cases, they land upright on their legs ("cat-like") on the ground or in the correct direction in small branches of shrubs and grasses. Experiments using high-speed cameras suggest that heelwalkers actively influence the landing position due to their highly flexible body axis (see Additional file 6: Video 2A and Additional 


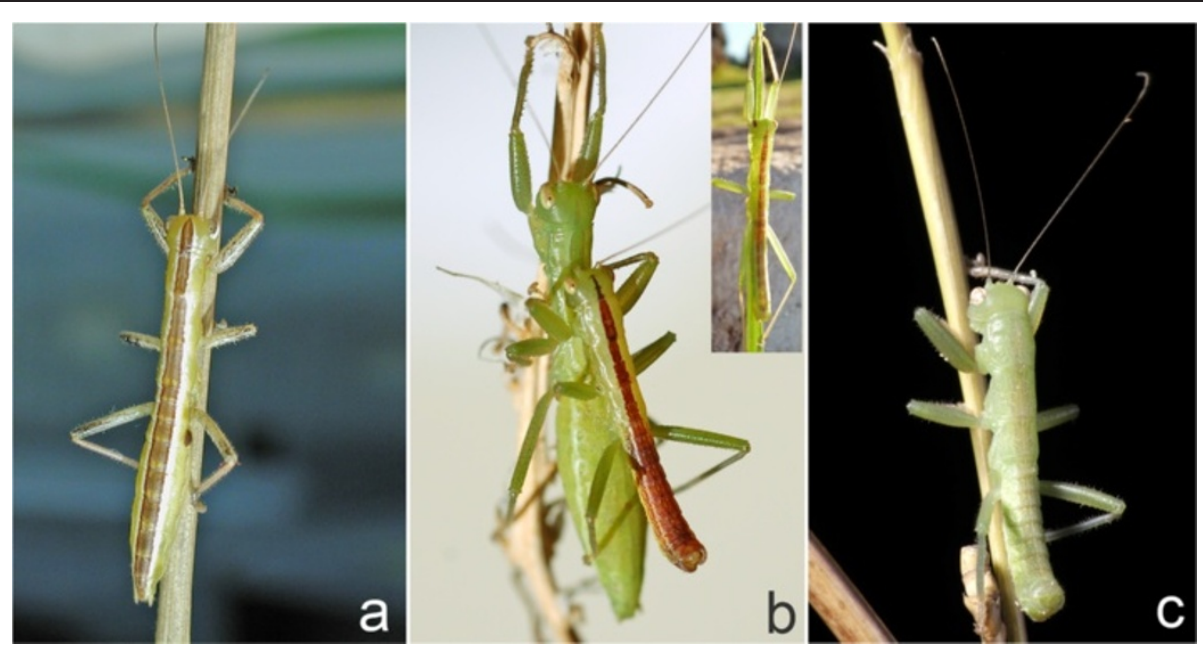

Figure 8 Development of brownish dorso-median stripes in different Mantophasmatodea taxa. a) Female Austrophasma gansbaaiense (S32, Gansbaai); the brownish stripe with white margins. b) Striatophasma naukluftense; the brownish stripe is only developed in males; females with less distinct green stripe. Western population (Gamsberg) with posteriorly broadened stripe. The inset shows a male from an eastern population (70 km E of Rehoboth) with distinctly outlined abdominal stripe. c) An undescribed species from the Richtersveld with weak male dorsal stripe development.

file 7: Video 2B). Similarly sized unwinged mantises and phasmids were unable to behave similarly; however, the mantises attempted to perform a 'loop', but required much more distance between the start and end points (Predel, unpublished). In the field and in captivity, healthy heelwalkers are reluctant to immediately walk away after dropping. When these insects did not land on their legs but on their backs, they changed their positions with a sudden

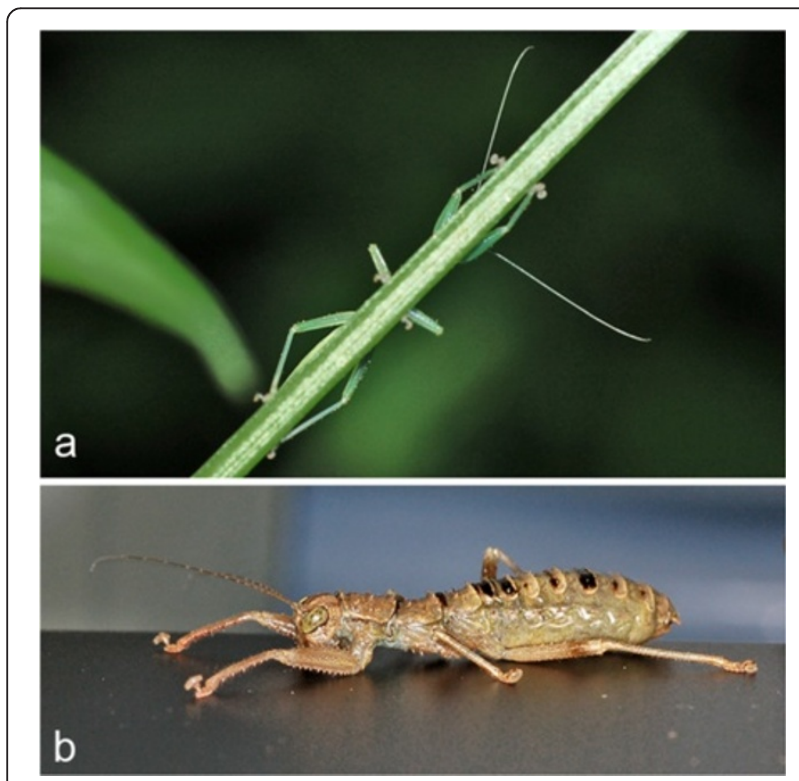

Figure 9 Mantophasmatodea females attempting to avoid detection under sudden light exposure. a) Mantophasma spec (N15, Waterberg) on a grass stalk at 11 p.m. (field observation); b) T. gladiator (N 38, Brandberg) (photo taken in laboratory). movement immediately after landing and stopped again (see Additional file 8: Videos 3A and Additional file 9: Video 3B). Due to this behavior, which may be maintained for $30 \mathrm{sec}$ or even longer, it is sometimes difficult to detect heelwalkers in detritus after beating a bush; many arthropods, such as ants, beetles, cockroaches, and spiders, run around actively under these circumstances. In nature, this strategy likely prevents detection by insect-hunting mammals or birds.

Both sexes possess very large arolia on the pretarsi of all legs (see [1,13-15]), which are, however, mostly held in an upright position; this highly characteristic position ("heelwalker") is quite unique among insects. Studies have shown that arolia are rarely used for walking, if at all, and are not necessary to produce, detect, or respond

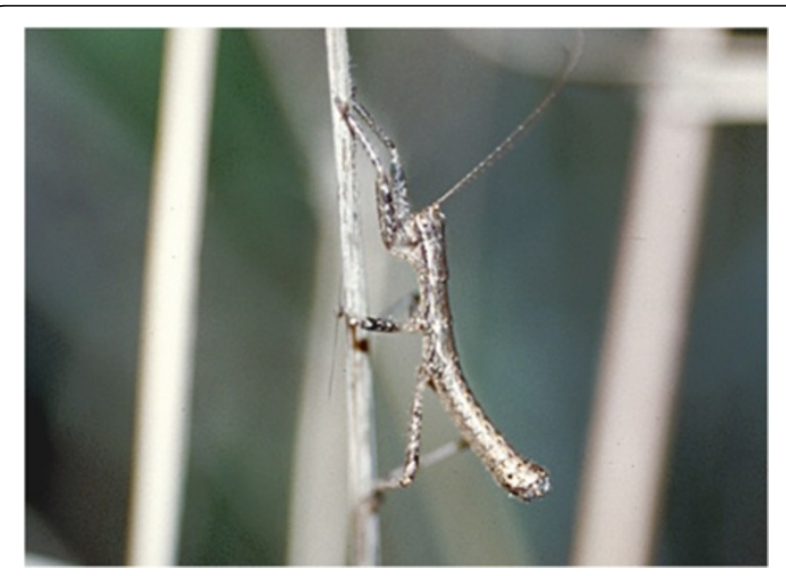

Figure $10 \mathrm{H}$. montaguense male (S29, Calitzdorp) in the field drumming at night (11 p.m.) on a grass stalk. 


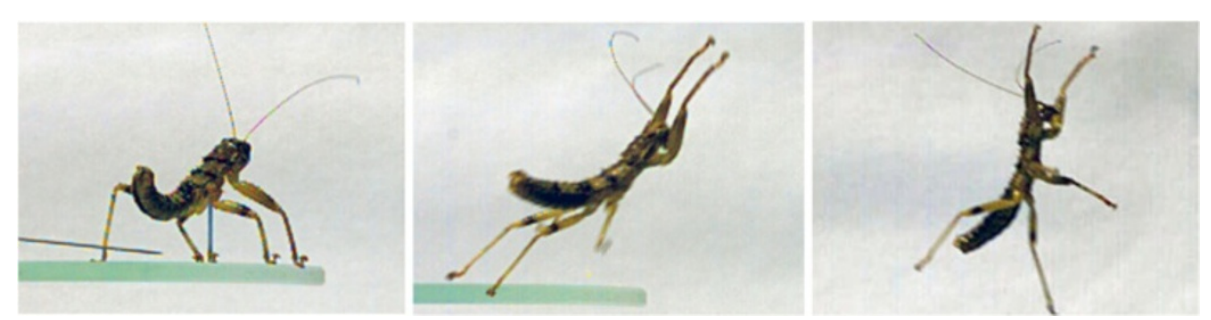

Figure 11 T. gladiator male (N 38, Brandberg) forced to jump from a glass slide. In contrast to grasshoppers, for example, Mantophasmatodea are typically reluctant to jump. (images from a video recorded in the laboratory).

to vibrational communication signals [15]. We observed arolia use when walking or adhering to smooth surfaces. For example, when cleaning body parts or eating large prey, the animals sometimes hung upside-down (Figures 6 and 12) and often used only a single hindleg arolium to adhere to smooth plastic surfaces. We also observed the insects using arolia to stabilize their position after landing or when a large prey was attacked (see Figure 7). Effective adhesion is supported by secretions produced in large glands in the arolia [15]. Secretion production is typically energy-consuming, which may be one reason to maintain the large arolia in an upward position when not in use. All species that have been maintained in our laboratory

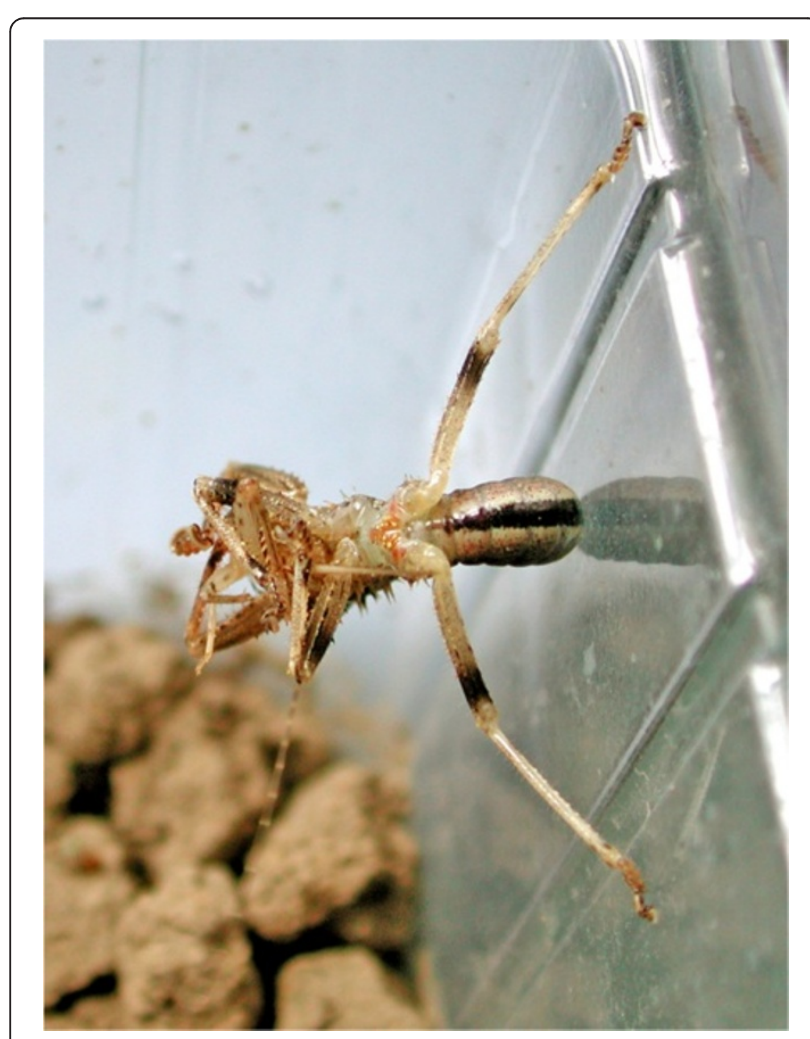

Figure 12 T. gladiator female (N 38, Brandberg) using hind leg arolia to adhere to the wall of a plastic container while eating a cricket. The fore- and hind legs were used to fix the prey (photo taken in the laboratory). frequently clean their arolia but also antennae and genital segments using their mouthparts (see Additional file 10: Video 4; also [5] for. T. gladiator)); tarsi were not used to clean any body part.

The Mantophasmatodea antennae are long, filiform, and have a flagellum well separated in basi- and distiflagellum; unique feature among insects $[4,17,18]$. While walking or hiding, these insects continuously wave their antennae in a manner similar to that of cockroaches (i.e., both antennae alternatively move up and down) (see Additional file 11: Video 5). During these motions, the flagellomeres are typically bent downwards. Antenna-flickering has been observed upon contact with a sexual partner and prey. This behavior indicates intensive chemical signal use. Potential glandular structures have been identified in two of the distal flagellomeres $[4,18,36]$. Occasionally, males walk with their abdomens upwards, similarly to scorpions (e.g., when approaching a sexual partner).

A diurnal habit has been observed in Mantophasma specimens (see also [5]). Occasionally, we found these insects sitting in the upper parts of grasses and outer shrub branches during the hottest portion of the day (11 a.m. 5 p.m.); however, the Mantophasma specimens were more abundant in these locations after nightfall. In the laboratory, Mantophasma specimens showed greater activity during the day compared with Austrophasmatidae species, including foraging and sexual behaviors (see [33] and below). For all species, mating and drumming behaviors were predominantly observed at night in the laboratory, including dusk and dawn.

\section{Life cycle, growth, and life history}

Mantophasmatodea are annual and univoltine species. Females oviposit in pods of foam that form a cocoon, which hardens due to incorporated sand and contains eggs from both ovaries (in T. gladiator 26-30, in Mantophasma females 20-24; Figures 13 and 14). Tojo et al., [19] reported 10-12 eggs in pods from K. biedouwense (Austrophasmatidae), which indicates that these insects may occasionally oviposit eggs from a single ovary (the egg number per ovary is similar to that of Mantophasma). These pods are laid superficially ( $0.5-2 \mathrm{~cm}$ deep) in sandy soil (Figure 15 ; see also [33]). In the field, we identified two empty pods 


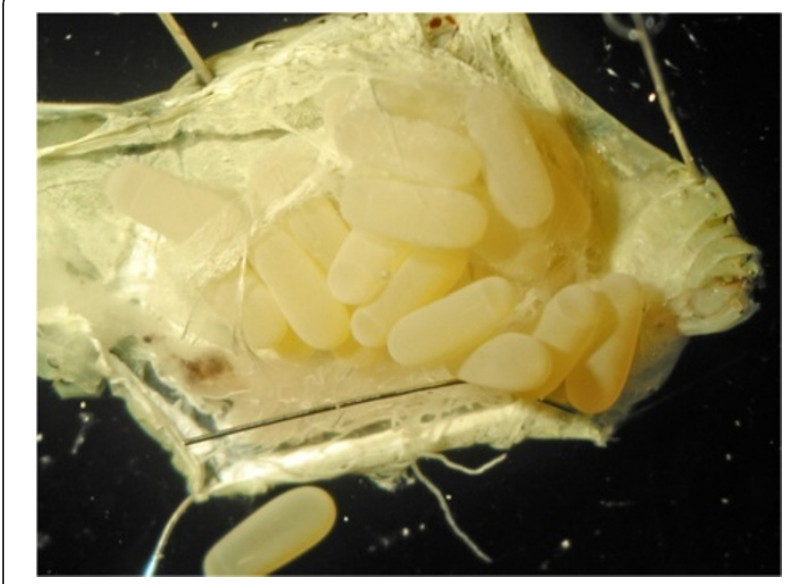

Figure 13 Female Mantophasma kudubergense (N21, Erongo Mts.) abdominal body cavity with 20 large eggs from both ovaries.

close together, which suggests that females do not hesitate to lay eggs at approximately the same spot. The pods are formed from sand and a secretory liquid to protect the eggs. In the pods, the eggs exhibit a regular vertical arrangement similar to that of bottles in a beer crate (see Figure 14). We did not observe sterile egg pod deposition, which is commonly observed in praying mantises [63].

Mantises and cockroaches, which were often collected at the same location as the heelwalkers, laid eggs/egg cases even under simplified laboratory conditions (e.g., in plastic boxes without a soil cover), but for Mantophasmatodea, oviposition was not observed under these simplified conditions. This reluctance to oviposit was evident. However, Mantophasmatodea specimens readily copulated in the

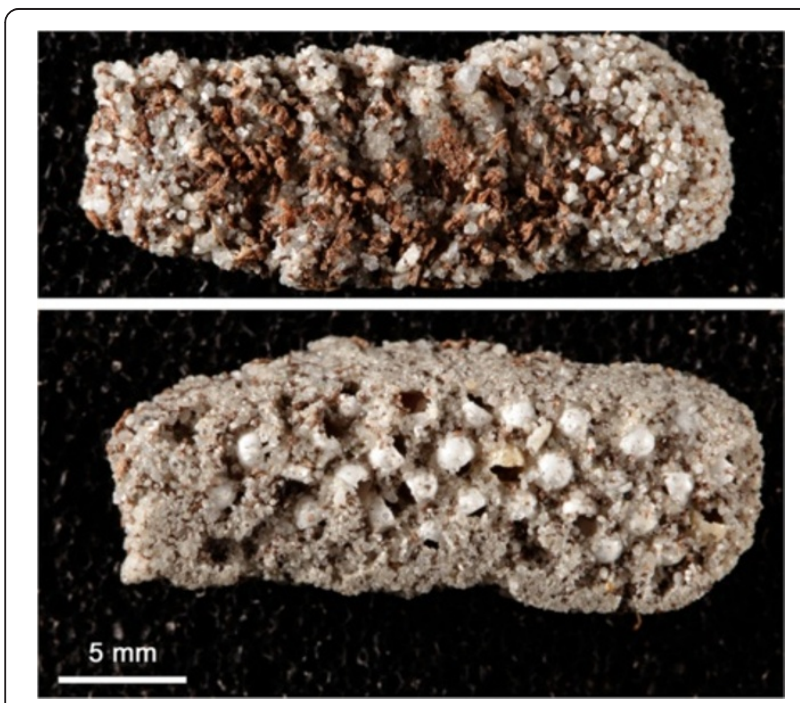

Figure 14 T. gladiator (N39, Brandberg) egg pod with 29 eggs laid into sand provided in the laboratory. Note the regular and vertical arrangement of the eggs, which became visible after the removal of the lower sand layer.

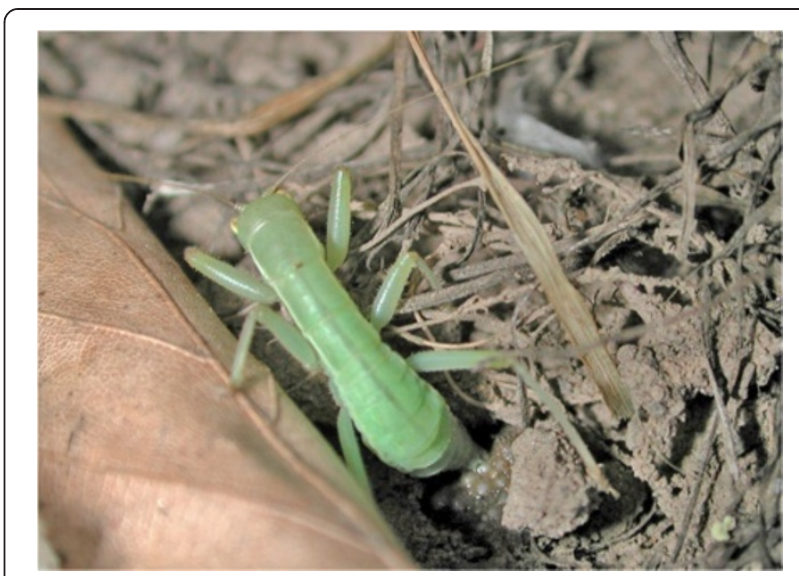

Figure 15 Mantophasma kudubergense female (N21, Erongo Mts.) laying an egg pod under laboratory conditions. The soil is not from the sample location.

laboratory if provided the opportunity (see below). Pregnant Mantophasmatodea females laid eggs almost immediately if sufficient soil was provided, and we obtained more than 30 pods with fertile eggs from $20 \mathrm{~T}$. gladiator females after copulation in the laboratory. Uchifune [64] obtained multiple egg pods from Karoophasma biedouwense (Austrophasmatidae); individual females laid up to four egg pods over a short period, i.e., a few days, and 50 100 eggs total during their adulthood [19]. In this species, oviposition was observed in September and typically occurred in the morning when the temperature was low and the humidity was high [64]. Under artificial laboratory conditions, Mantophasmatodea breeding was unsuccessful in most cases. We tested different dormancy scenarios using T. gladiator egg pods (G. Köhler, unpubl. data). Neither a dry and warm period over several months nor dry conditions followed by a cooling $\left(4^{\circ} \mathrm{C}\right)$ period over several months initiated hatching. In all scenarios, a water supply was used to terminate dormancy, which simulated the rainy season and appeared to initiate hatching in the field. The egg fertilization rates varied from $48-95 \%$ in our experiments, and the embryos reached the anatrepsis phase. From these observations, we assumed a diapause. However, successful rearing in Sclerophasma paresisense and Praedatophasma maraisi (in fact, Tyrannophasma gladiator, see locality) was reported by [17], who used increased moisture and rising temperatures following a cold period.

In nature, the egg stages survive at least eight months of a dry summer (Austrophasmatidae) or winter (Mantophasmatidae, Tanzaniophasmatidae) within the resistant egg pods, and the first instar nymphs hatch the following year during the rainy season (i.e., in mid-summer for Namibia/East Africa and autumn/winter (May or later) for South Africa) (see also [17,19]). In the Naukluft Mountains (Namibia), we identified multiple $(n>20)$ first instar Striatophasma naukluftense nymphs [45] in the morning 
14 days after a strong summer rain; scattered along a section of $200 \mathrm{~m}$. The same section was searched the previous evening without success. This finding suggests highly synchronized egg hatching from different pods during the night (see also [17] for observations on Karoophasma). Analyzing the occurrence of nymphs and adults of different Austrophasmatidae species in South African sample sites, we found that development varied considerably at the local scale throughout two subsequent years (Figure 16), depending on the local rainfall patterns and latitude. These observations indicate highly variable life history patterns on both species and population levels as an adaptation to local climate heterogeneity. In Namibia at the end of March 2014, we collected Striatophasma (Hakos Mountains) and Mantophasma (Emeritus farm) adults and first instar nymphs in the same habitat. For the Hakos locality, detailed precipitation recordings exist and verified strong rainfall at the end of December 2013 and again in mid-March (see Figure 16). Therefore, facultative bivoltine behavior may occur during a long rainy season but this scenario needs to be verified experimentally. Other than the direct influence of rainfall on egg development, there is no information on which additional factors induce the end of dormancy in eggs after the dry period. Under dry experimental conditions and room temperature, most $T$. gladiator embryos remained alive after two years. Similarly prolonged egg dormancy is also known from other Polyneoptera inhabiting semi-deserts; in Southern Africa eggs of the armoured ground cricket Acanthoplus bechuanus (Orthoptera) are able to undergo dormancy at least for two years [65].

T. gladiator nymphs that hatched reached adulthood after 3.5-4 months [5]; the adults survived at least two months in our laboratory. First instar Striatophasma naukluftense nymphs were collected and reared; the oldest adult died at 136 days (4.5 months). For the winter-

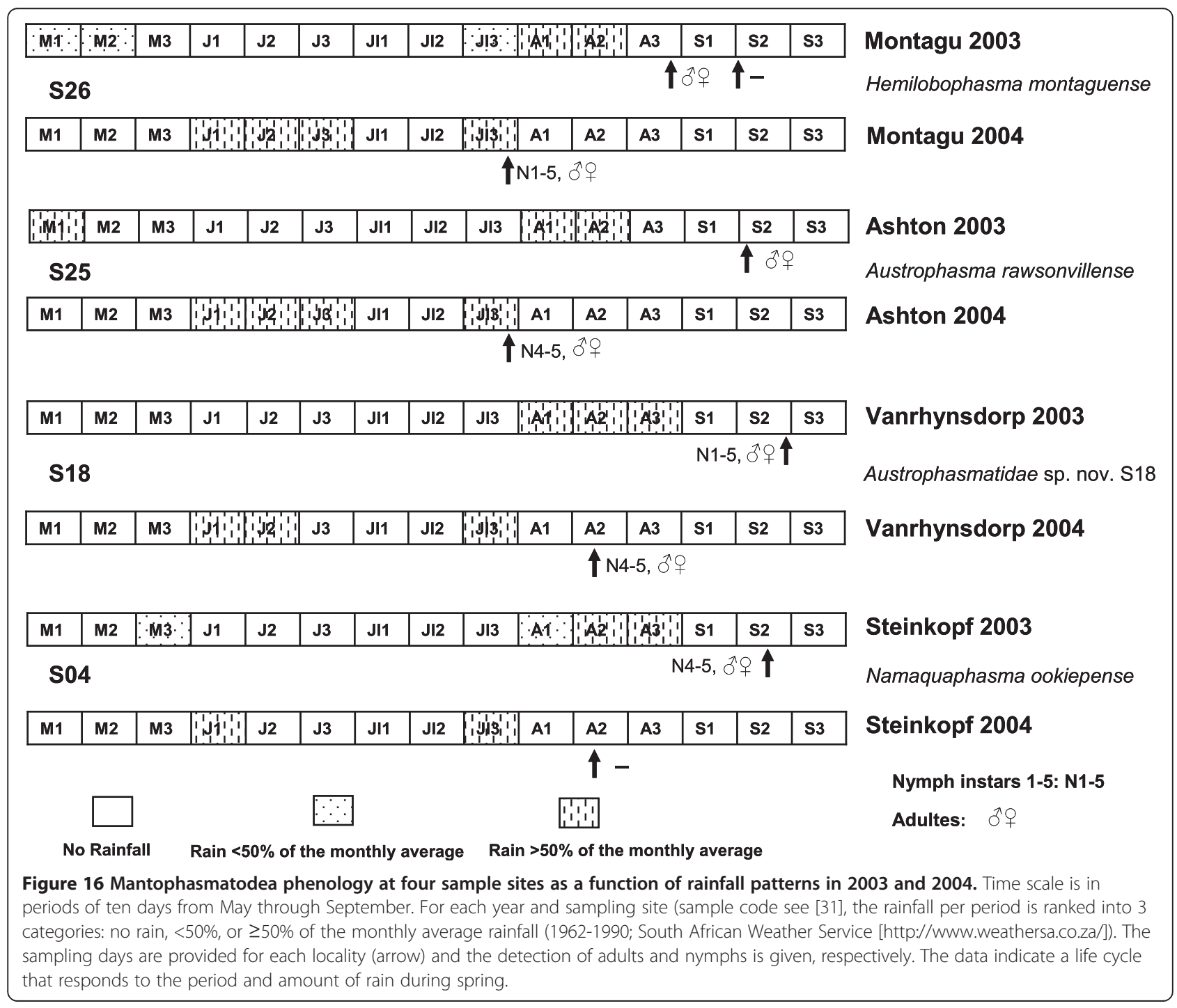


active Austrophasmatidae species, the developmental period appears to be shorter, but the unpredictable weather conditions strongly influence their life spans. Drilling and Klass [17] indicated approximately 55 days (excluding the first instar phase) in L. redelinghuysense; our laboratory experiments $\left(21-23^{\circ} \mathrm{C}\right)$ have shown that third instar Austrophasmatidae larvae (localities: S04, S15, S18, S26, S32; see Figure 1) reached adulthood within less than a month. In the laboratory, we observed a shorter life span in males compared with fertile females. Typically, Mantophasmatodea molted during the night and ingested their exuviae; therefore, counting the number of instar stages for these insects was difficult. In only a few cases, the fragile Mantophasmatodea exuviae were found hanging on the top or wall of the rearing container. Hockman et al., [17] used antenna development (i.e., the increasing number of basiflagellum annuli) as the criterion for assessing instars and reported 5 nymph instars in L. redelinghuysense. The first instar nymphs possessed four annuli in the basiflagellum and seven hairy annuli in the distiflagellum. For each instar, two additional annuli were derived from the most basal annulus (meriston); therefore, the number of annuli in the adult $L$. redelinghuysense basiflagellum was 14. Because consistent antennal development was also observed for other mantophasmatodean taxa [17], the assumed 8-10 instars in T. gladiator [5] is likely an overestimate.

There is no available information on mortality factors, including predation and parasitism, in the field. Camouflage appears to be important for these small predators, which are vulnerable to attack by birds, lizards, and predaceous insects that are present in the same microhabitat. Escape behavior, i.e., jumping away from a bush or grass tussock, was rarely observed. However, heelwalkers can jump for a short distance (see above). In particular, the summer-active Mantophasmatidae species regularly co-occur with mantises, mainly the genus Miomantis, which were collected using the same collection method. However, on the microhabitat scale, we found that a high heelwalker density was primarily linked to relatively low mantis abundance, even if mantises were more frequent elsewhere in the immediate neighborhood. Although we did not perform quantitative studies, this observation indicates extermination or possible avoidance of intra-guild predation between these insects.

\section{Prey and feeding behavior}

Mantophasmatodea are carnivorous insects. Similarly to many other predatory insects, they may be generalists regarding their prey [66] because they consume different types of arthropods, mainly spiders and insects. Mantophasmatodea clearly coincide with microhabitats that have a high arthropod density. Co-occurrence with other predators, as mantises, was rare in the winter rainfall range
(Austrophasmatidae), but common in Namibia; however, co-occurrence was not observed in the same microhabitat (see above). We did not observe heelwalkers in bushes with high ant abundance. However, this phenomenon does not exclude ants as prey. We investigated the gut content of 14 specimens from Mantophasma spec. (N15, Waterberg) at different nymphal stages and in adults collected at 5:30 p.m. and 11:00 p.m.; we primarily found remains of ants, other adult Hymenoptera, Diptera, caterpillars, and moths, as well as different size spiders. In a single sample, oribatid mite remains were detected. However, phytophagous locusts, bugs, or beetle remains were not observed. Four of the 14 Mantophasma specimens did not contain food remains in their gut $(3 \times 11: 00$ p.m., $1 \times 5: 30$ p.m.). In an investigation under laboratory conditions, fasting Mantophasma sp. males from Waterberg $(\mathrm{N} 15 ; \mathrm{N}=5)$ were fed small crickets and dissected at $1 \mathrm{~h}$ intervals. After two hours the mid-gut contained considerable quantities of partially digested cricket (Figure 17). However, the foregut stored food remains for many hours. Therefore, food in the foregut does not necessarily reflect recent intake. From these experimental data, we concluded that at least two out of eight (25\%) Mantophasma specimens (N15) collected at 11 p.m. consumed a meal a few hours in advance. In contrast, the six specimens collected at 5:30 p.m. did not show signs of a recent meal. One specimen from the same location was collected at 7 a.m., and both the foregut and mid-gut were entirely filled with food particles. These experiments indicate hunting activity during the evening and at night.

To further survey the Mantophasmatodea food spectrum, we investigated the potential prey from a single bush (Suaeda fruticosa, Amaranthaceae) at 8 a.m. in the dry Richtersveld (South Africa), which yielded four adult specimens from an undescribed Mantophasmatodea taxon (Figure 18). In total, we collected 12 mites (2 species), 2 pseudoscorpions, 32 spiders (6 species; most individuals

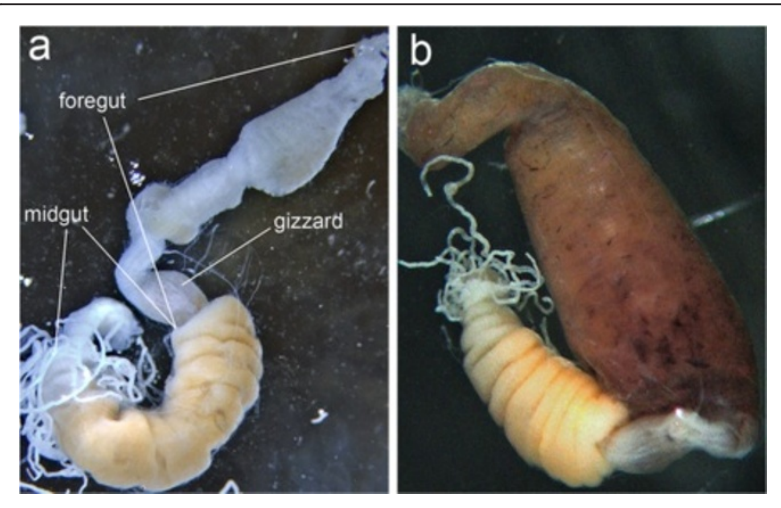

Figure 17 Dissected adult Mantophasma spec. (N15; Waterberg) gut tissues before (a) and $\mathbf{2} \mathrm{h}$ after (b) feeding with crickets. In the latter specimen, the gizzard and mid-gut contained food particles $2 \mathrm{~h}$ after the meal. 


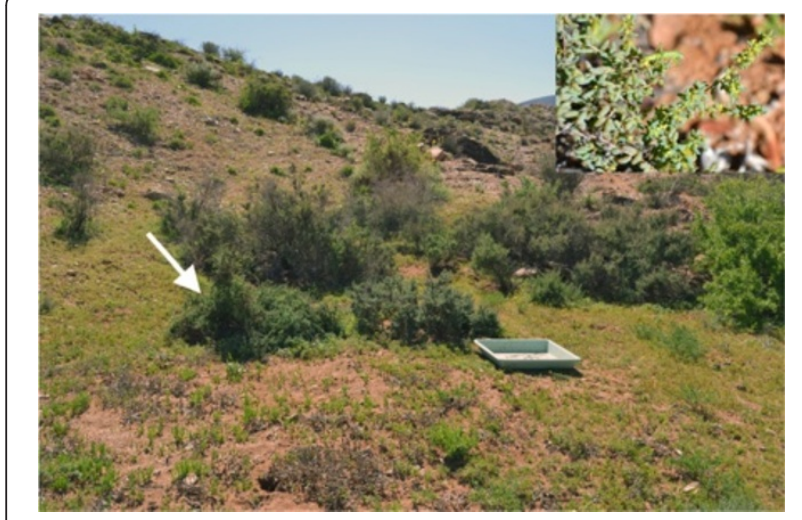

Figure 18 A Suaeda fruticosa (arrow) sample site with four adult Mantophasmatodea specimens (8 a.m.). In addition to the Mantophasmatodea, we collected the remaining arthropods from this bush to survey the potential prey spectrum. Subsequently, the gut content of the four Mantophasmatodea specimens and the identity of the collected arthropods were analyzed in the laboratory.

less than $3 \mathrm{~mm}$ ), a single termite, 7 adult Psocoptera, 19 small, adult Heteroptera (likely Geocoridae), 3 Homoptera nymphs, 1 myrmicine ant, 1 caterpillar, 1 plume moth, 9 adult Coleoptera (7 Curculionidae, 1 Nitidulidae, and 1 Latridiidae), 2 phytophagous beetle larvae, and 4 winged Diptera (3 Brachycera and 1 Nematocera); a few Diptera escaped. The prey remains in the guts of the four Mantophasmatodea collected from the same bush indicated that each specimen consumed a meal the night before, but the gut contents did not entirely reflect the potential prey spectrum (the prey spectrum that was present in the morning). In the gut lumen of these Mantophasmatodea, we found brachyceran fly remains; additional remains were assigned to a caterpillar, a spider, and a few small adult insects (likely Holometabola) that were not identical to the species listed above.

The literature includes only a few observations on how Mantophasmatodea find and handle their prey in the field [5,33]. A hide and wait strategy (in combination with slow stalking) is very likely and is concordant with the nocturnal activity of most species. In the laboratory, Mantophasmatodea nymphs and adult Austrophasmatidae were mainly fed different Drosophila species. Larger Mantophasmatidae and Tanzaniophasmatidae specimens were fed house and flesh flies, as well as different size Gryllus nymphs. Additional prey that were successfully provided in captivity include mosquitos, plant hoppers, booklice, moths (including larvae), termites, bush crickets, antlion lacewings, may flies, and small earthworms. Adis et al., [33] also fed the insects dead mealworms (Tenebrio). In captivity, crickets were refused as prey by many Austrophasmatidae, but not Mantophasmatidae. For T. gladiator, [5] suggested that cockroaches and moths were prey in the Brandberg area. In a single experiment, we placed two late instar Mantophasma spec. nymphs (N21, Erongo Mountains) with a mantis nymph (Miomantis sp.) of the same size and from the same locality in a plastic box $(100 \times 100 \times 40)$. The mantis was the prey. Cannibalism among nymphs and adults (also between females) has been regularly observed in captivity (see also $[19,33]$ ). In certain instances, females have successfully attacked males after mating or without mating contacts in both small pots and larger cages.

When hunting Drosophila, Mantophasmatodea waited or sometimes walked a few millimeters to the flies. With a sudden motion, they moved forward and caught the prey with their mandibles (see Additional file 12: Videos 6A, Additional file 13: Videos 6B, Additional file 14: Videos 6C and Additional file 15: Videos 6D). Thus, small prey, such as fruit flies, can be caught without using the legs. Occasionally, we observed that Mantophasmatodea used the tarsi of a foreleg to catch a fruit fly and bring it to their mouthparts. The insects embrace (face-to-face) larger prey using their spiny forelegs and, often, their mid-legs (Figure 12; see also [5] for T. gladiator); the prey is immediately consumed. In a single case, we removed an A. gansbaaiense female's victim (a male of the same species) immediately after the first attack to the neck and found the ventral nerve cord severed. This behavior was not consistent, but [5] also reported initial neck bites with larger flies. Meal consumption requires a short time and does not necessarily exclude body appendages (see Additional file 16: Video 7). Adis et al., [33] observed that Mantophasmatodea occasionally bite their prey's head off (e.g., Musca). We occasionally observed this behavior when we fed the Austrophasmatidae specimens using Drosophila. In few cases, the heelwalkers only used the heads for eating/feeding and neglected the remaining bodies from up to ten fruit flies.

\section{Sexual behavior \\ General remarks}

All Mantophasmatodea species exhibit strong sexual dimorphism in the external genital structure [4], and males are, on average, smaller and more slender compared with females. The male reproductive system includes testes, a deferent duct, seminal vesicles, and accessory glands [7] and is proliferated in the abdomen. Depending on the species, pregnant females have 8-15 eggs per ovary, which are surrounded by a thin cover of tissue and typically oviposited in a single pod (but see also [19], which includes a description of pods with 10-12 eggs). The female's weight increases remarkably during egg maturation (wet weight in g) (e.g., Mantophasma kudubergense (0.14-0.22) [5] and Austrophasmatidae sp. n. (0.063-0.152; S18, Vanrhynsdorp)). For Karoophasma biedouwense and Hemilobophasma montaguense, 50-100 eggs total per lifetime have been reported [19]. Under laboratory conditions, 
Mantophasmatodea mate readily; therefore, we observed different aspects of their sexual behavior, such as sexual communication, partner finding, courtship, and copulation, in several species and compared these data with previous descriptions in [20].

\section{Drumming behavior}

Both sexes use single vibrational calls, which are produced by tapping the abdomen onto the substrate (see Additional file 17: Videos 8A and Additional file 18: Video 8B), for mate location and recognition [20]. The male subgenital plate has a semicircular lip-like process of taxon-specific extension ([1,4]; Figure 19), which temporarily contacts the surface during drumming (='drumstick'). Females do not develop this abdominal process and tap with the middle part of their ventral abdomen. Female calls consist of single repeated pulses, whereas male calls are more complex pulse trains that likely contain coding for species recognition. Eberhard and Picker [20] detailed a behavior associated with duet drumming in $K$. biedouwense. The males randomly emitted drumming calls to test their environment for receptive females, whereas the females typically drummed in response to the male calls. After stimulation by a male, the females stopped walking, began drumming, and rapidly moved their antennae. In response, males initiated rapid antennal movement, rubbed their abdomen on vertical stems before drumming, and, finally, began their partner-searching behavior. Rubbing the abdomen appears facultative because we did not observe this behavior before drumming in our laboratory experiments. Substrate vibration is likely detected by leg scolopidial organs [21].

An analysis of two sympatric Austrophasmatidae (Viridiphasma clanwilliamense and Karoophasma biedouwense $[20,44]$ species revealed different call parameters

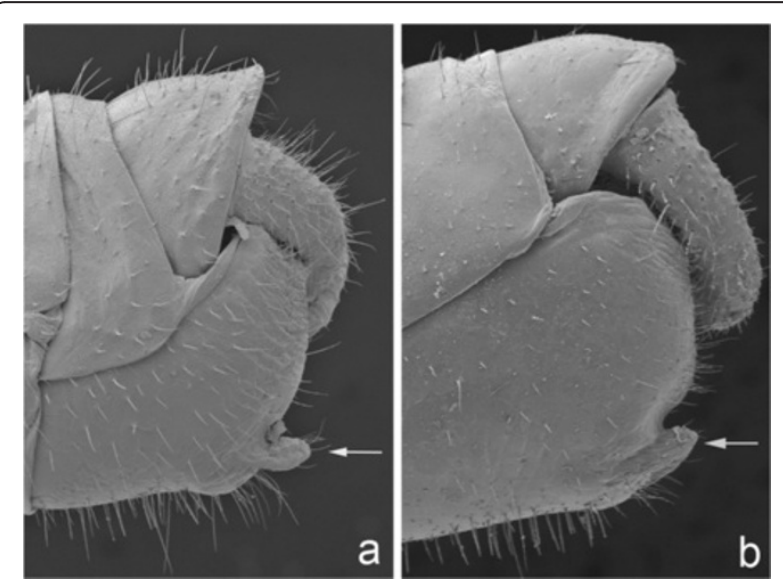

Figure 19 SEM micrographs showing taxon-specific development of male subgenital plates (arrow) from Pachyphasma brandbergense and Striatophasma naukluftense. (modified from [45]). in both species and a clear preference for conspecific calls. However, most Mantophasmatodea species are not sympatric [31], and species recognition via species-specific call parameters may be relatively unimportant. This assumption was partially confirmed by [22], who analyzed vibrational communication in 13 Mantophasmatodea species, which included 11 Austrophasmatidae and two Mantophasmatidae species from Namibia. Nevertheless, slightly different call parameters were reported for all species studied. For females, a greater pulse repetition time in Austrophasmatidae was observed compared with species from Namibia [22]. For our report, we studied vibrograms and temporal call characteristics for male Striatophasma naukluftense from Namibia (Figure 20, Table 1). We studied the following five parameters for the male calls: 1 ) pulse repetition time (the time between single beats), 2) number of pulses per pulse train, 3) pulse train duration, 4) inter-pulse train intervals (the time between the end of one pulse train and the beginning of the next pulse train), and 5) pulse train repetition time (the time between initiating two pulse trains). For reasons explained below, only the first three parameters are presented here (see Table 1). In addition, we analyzed six males from the Mantophasma/Sclerophasma clade, which currently consists of Sclerophasma paresisense and several Mantophasma species. In contrast to the specimens studied in [22], our six Mantophasma/Sclerophasma specimens originated from different localities/populations (see Figure 1). The calls from these males were similar in structure, but the temporal patterns of all measured characteristics (see Table 1) differed significantly (Kruskal-Wallis test results are not shown). When comparing coefficients of variation (CV) values of the measured calls with those reported for other Mantophasmatodea species (CVs for all parameters $<15 \%$, see [22]), we found similar CV values for the duration of pulse trains and the number of pulses/train (CVs: 0.4-17\%, see Table 1). In contrast, the pulse repetition time had much higher CVs on inter-individual level (38\% and 57\% for Striatophasma and Sclerophasma/Mantophasma, respectively) in our analysis compared with the study by [22]. Because the intra-individual comparisons did not demonstrate this variation, we excluded a systematic error. The number of individuals investigated was low and further specimens have to be investigated, but the obtained intra-specific variability in Striatophasma and Mantophasma already suggests variation at the population level. A direct comparison of call parameters obtained in our analyses with those reported in [22] is complicated by incorrect assignments (and GPS data) for their Namibian species; the calls assigned to specimens from the Brandberg should be from Tyrannophasma gladiator instead of Sclerophasma paresisense, and the calls assigned to specimens from Paresisberge should be from Sclerophasma paresisense instead of Praedatophasma maraisi. A notable 


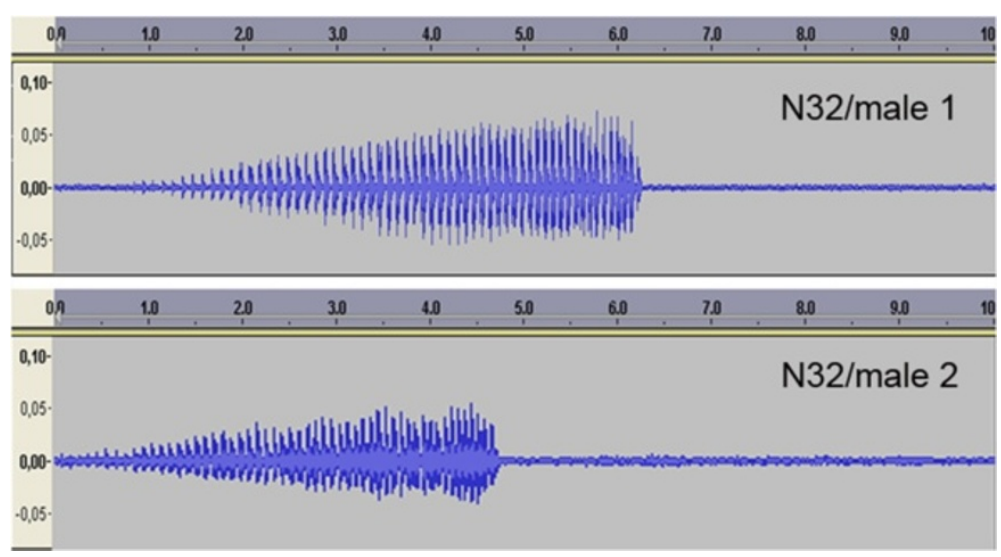

Figure 20 Vibrogram of substrate vibrational signals of two male Striatophasma naukluftense. The specimens were caught at Gamsberg Pass, Namibia (N32); the signals were recorded at ca. $20^{\circ} \mathrm{C}$ in the laboratory. The male call consists of repeated pulse trains and one pulse train for each individual is shown. The duration of pulse train is about $6000 \mathrm{~ms}$ (male 1) and $4500 \mathrm{~ms}$ (male 2), respectively. Note the increasing amplitude in the first segment and the more constant amplitude in the second segment of the pulse train.

difference between our analyses and [20,22] is that their recordings were collected during the day, and the insects were stimulated. In our recordings, the Austrophasmatidae species (not shown) drummed spontaneously, but only during the evening, at night, and, occasionally, in the morning. In contrast, both sexes in Mantophasma were also observed drumming during the day (see also [5]); however, the main drumming activity occurred at night without a detectable activity window. In general, the intraand inter-individual variability in call parameters were

Table 1 Temporal characteristics of vibrational signals for three males of Striatophasma naukluftense and six males from the Sclerophasma/Mantophasma clade

\begin{tabular}{|c|c|c|c|}
\hline Taxa & $\begin{array}{l}\text { Pulse repetition time } \\
\text { (ms)/CV(\%) }\end{array}$ & $\begin{array}{l}\text { Pulse train duration } \\
(\mathrm{ms}) / \mathrm{CV}(\%)\end{array}$ & $\begin{array}{l}\text { Number of pulses per pulse } \\
\text { train/CV(\%) }\end{array}$ \\
\hline \multirow[t]{2}{*}{ Striatophasma (N32) } & $19.46 \pm 2.16 / 11 \%$ & $5365.4 \pm 409.6 / 7 \%$ & $57.4 \pm 5.38 / 9 \%$ \\
\hline & $n=70$ & $n=7$ & $\mathrm{n}=7$ \\
\hline \multirow[t]{2}{*}{ Striatophasma (N32) } & $19.2 \pm 2.41 / 125 \%$ & $4395.7 \pm 221.7 / 5 \%$ & $50.2 \pm 3.3 / 7 \%$ \\
\hline & $n=40$ & $n=4$ & $n=4$ \\
\hline \multirow[t]{2}{*}{ Striatophasma (N33) } & $35.6 \pm 2.43 / 6 \%$ & $2537.5 \pm 323.3 / 13 \%$ & $28.8 \pm 2.93 / 10 \%$ \\
\hline & $n=60$ & $n=6$ & $n=6$ \\
\hline Average (N32,N32,N33) & $24.75 \pm 9.39 / 38 \%$ & $4099.53 \pm 1437.02 / 35 \%$ & $45.46 \pm 14.8 / 32.5 \%$ \\
\hline \multirow[t]{2}{*}{ Sclerophasma (N14) } & $21.03 \pm 3.77 / 17 \%$ & $1300 \pm 122.5 / 9 \%$ & $14.89 \pm 1.17 / 7 \%$ \\
\hline & $\mathrm{n}=90$ & $n=9$ & $n=9$ \\
\hline \multirow[t]{2}{*}{ Mantophasma (N9) } & not analyzed & $1939.2 \pm 266.7 / 13 \%$ & $20.7 \pm 2.6 / 12.5 \%$ \\
\hline & & $n=11$ & $\mathrm{n}=11$ \\
\hline \multirow[t]{2}{*}{ Mantophasma (N10) } & $24.05 \pm 7.5 / 31 \%$ & $2059.5 \pm 277.8 / 13 \%$ & $24 \pm 3.0 / 12.5 \%$ \\
\hline & $n=60$ & $n=6$ & $n=6$ \\
\hline \multirow[t]{2}{*}{ Mantophasma (N15) } & $39.03 \pm 3.65 / 9 \%$ & $1689 \pm 83.3 / 4 \%$ & $19 \pm 0.9 / 5 \%$ \\
\hline & $n=60$ & $n=6$ & $n=6$ \\
\hline \multirow[t]{2}{*}{ Mantophasma (N20) } & $74.08 \pm 4.7 / 6 \%$ & $1628.6 \pm 111.3 / 7 \%$ & $12.1 \pm 0.9 / 7 \%$ \\
\hline & $n=70$ & $n=7$ & $n=7$ \\
\hline \multirow[t]{2}{*}{ Mantophasma (N31) } & $78.5 \pm 2.12 / 2 \%$ & $3205 \pm 15 / 0.4 \%$ & $13 \pm 0$ \\
\hline & $n=20$ & $n=2$ & $n=2$ \\
\hline Average (N9,N10, N14, N15, N20, N31) & $47.34 \pm 27.33 / 57 \%$ & $1970.22 \pm 660.1 / 33.5 \%$ & $17.33 \pm 4.79 / 28 \%$ \\
\hline
\end{tabular}

The data are the mean \pm standard deviation; $n=$ number of measured values analyzed per individual. For pulse repetition times, each pulse train was measured 10 times and then averaged. CV = coefficient of variance (i.e., standard deviation/mean (rounded)); localities (N9-N33) in accordance with [31]). 
expressed as CVs that ranged from 10-40\% ([22]; this study) and were in the variation range for communication in other insects (23.6\% average CV; [67]).

Based on the studies conducted using Mantophasmatodea, the following questions remain. 1) It is not clear whether repetitive pulse trains constitute a single call, as proposed in [20] and [22]. Alternatively, repetitive pulse trains could compose consecutive calls. 2) Certain parameters studied ([20,22], and this study) are inter-correlated. The number of pulses per pulse train might depend on the pulse train duration. As another example, the pulse train repetition time is the sum of the inter-pulse train interval and pulse train duration. It is difficult to determine which parameter is most important for females to discriminate among male calls from different species because of these strong inter-correlations. 3) In insect communication, call performance also depends on the specimen condition and ambient temperature (Boumans, pers. communication). Stonefly studies have demonstrated that temperature has an important impact on the frequency but not the number of pulses [68]. However, physical constitution affects the number of pulses per pulse train (Boumans, in prep.). After submitting the manuscript, the authors collected in the Richterveld (South Africa) males of two different species (Namaquaphasma ookiepense; Austrophasmatidae gen. n. sp. n. S01) in the same bush and placed them in separate plastic boxes in the field. The $N$. ookiepense males produced short pulse trains of about a second (see also [22]). In striking contrast to these short signals were the pulse trains of the second species which lasted 4-6 sec.

\section{Courtship and mating behavior}

If maintained in spacious cages, mating in Austrophasmatidae species primarily begins in the evening or at night. In contrast, mating of several Mantophasma specimens was observed at any time of day. Eberhard and Picker [20] hypothesized that males were attracted chemically through female pheromones over a long range and through continuous vibrational communication in a median range, such as where both partners are in the same bush. However, even if vibrational communication is part of a heelwalker's sexual behavior, it is not an obligate behavior for locating a sexual partner in the laboratory (see also [20]). If males and females were placed at different edges of a cage $(200 \times 200 \times 300$, with a grass tussock structure), they found each other without drumming. Sexual partners seemed to notice each other from approximately $8-10 \mathrm{~cm}$. As they neared each other, rapid antennation (i.e., flickering of their antennae) occurred (see [20]), which indicates odor-mediated sexual communication. This approach was often interrupted by phases without movement. In most cases, the antennae did not directly contact the partner (see also [5]), but occasionally, contact was made. We frequently observed the males moving their abdomens up and down, while the females approached the males over a short range or continuously beat their abdomens on the surface/substrate. In one case, we observed a Hemilobophasma montaguense female that walked back and forth $3 \mathrm{~cm}$ in front of a male; suddenly, the female stopped and moved her abdomen up, and immediately, the male moved closer and mounted. Males mount rapidly. If the male's head was initially directed towards the tip of the female abdomen, the male quickly rotated until their heads were aligned (see Additional file 19: Video 9). Copulation occurs through a false male-above mating superposition, and males hold the females with their fore- and midlegs. Eberhard and Picker [20] reported arolia use during copulation, but this behavior was only observed (if ever) during the first second(s) of mounting to stabilize their position. Shortly after mounting, the males hold their arolia upwards again. For copulation, males extend their abdomen to the right side of the females, forming an "s" shape, while females project their abdomen upwards. Fixing the genitalia on the left side of the body was not observed (see also [20]). The male cerci are used as claspers to bring the genitalia of sexes close together. The large male genitalia evaginate and insert into the vagina (morphological description in [4]). During prolonged mating (see below), males remain mounted regardless of the female's behavior. During copula, we observed females walking, stalking, catching prey (see Additional file 20: Video 10), and excreting (see also [20]). Even if a female dropped down from the grass, the male remained sitting on the female's abdomen afterwards. Occasionally, we found males mounted on dead females. Both partners groomed during copula. When cleaning the forelegs, males occasionally stood with only their midlegs on the females, while the hind legs were held upwards. Under these circumstances, we observed that male midleg arolia contacted the female body. Except for grooming, the males did not move during copula; even the antennae did not flicker (see Additional file 11: Video 5). This observation might be interpreted as a behavioral adaptation to minimize the energy loss during the extended copulation time. The position of males during copulation was typical of Mantophasmatodea (Figure 21) and included upholding the hind legs, as well as resting from antenna flickering.

The males generally appear to be at risk of attack by the female, as indicated by their rapid mounting. Zompro et al., [5] reported that Mantophasma kudubergense males retreated by jumping away if the females appeared agitated after mounting. In Austrophasmatidae sp. n. (S18, Vanrhynsdorp), we observed that a female defended herself against a mounted male by both leg kicking and biting (see Additional file 21: Video 11). The elements of sexual behavior, such as drumming, antennae flickering for chemical cues, and antennae contact, can be interpreted 

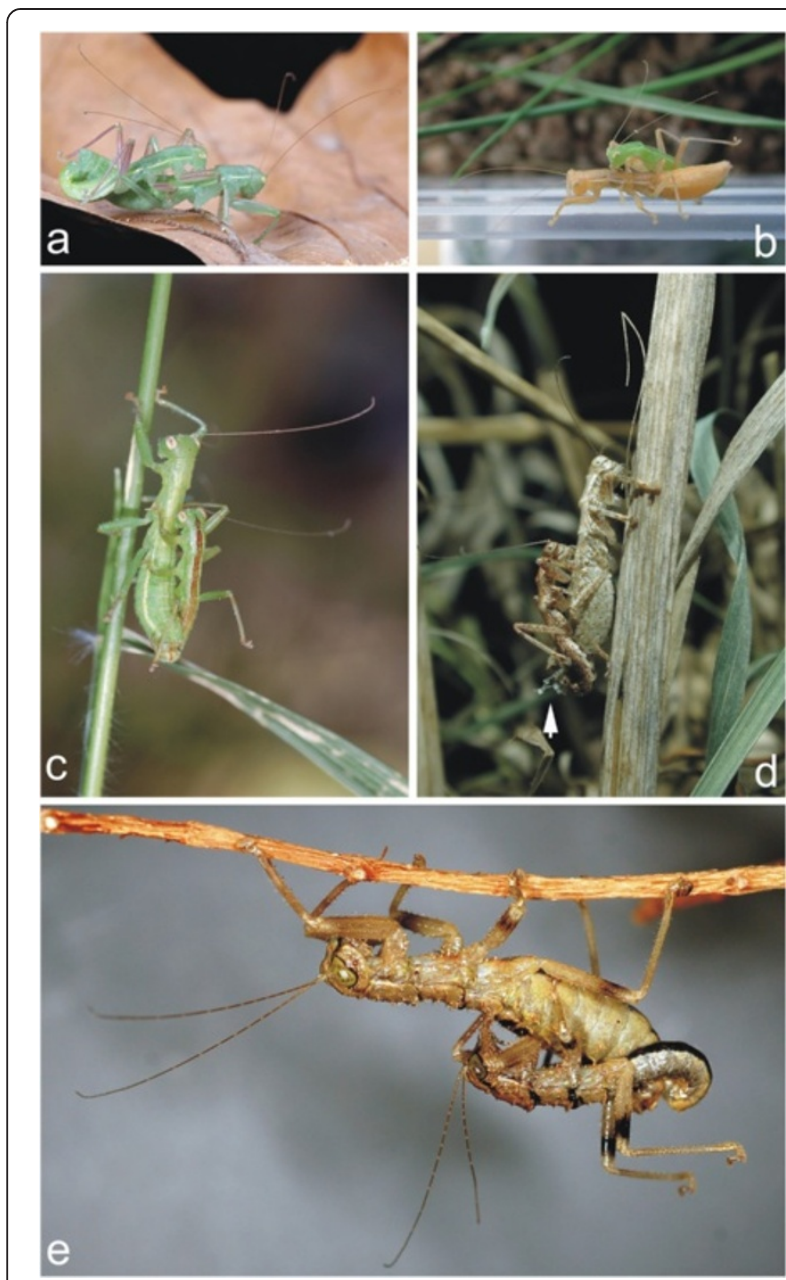

Figure 21 Typical mating position of Mantophasmatodea. (a) Mantophasma spec. (N15, Waterberg); righthand view. (b) Mantophasma kudubergense (N21, Erongo Mts.) with different color morphs; lefthand view. (c) Striatophasma naukluftense (N35, Naukluft Mts.; from [45]). (d) Austrophasmatidae sp. n. (S18, Vanrhynsdorp), with a conspicuous semi-liquid and gelatinous substance (arrow) between the external genital structures. (e) T. gladiator ( $N$ 38, Brandberg). Note the uniform position of the hind legs and antennae in males.

as species recognition behavior [20] or courtship behavior to reduce female attacks; the elements might be involved in both behaviors. As described for Mantophasma kudubergense by [33], we observed intense pumping movements at the tip of the abdomen for Austrophasmatidae males; thereafter, spherical eversion of the phallic lobes was observed. Eberhard and Picker [20] considered this action an indication of direct sperm transfer from males to females. This behavior was observed during the first 12 min of copulation and at least three times during the first hour of copulation. In our observations we did not identify similar time patterns for pumping in Austrophasmatidae. Pumping occurred at different periods during prolonged copulation. In Austrophasmatidae sp. n. (S18,
Vanrhynsdorp) we observed a semi-liquid, gelatinous substance between the external genital structures of males and females during the last phase of copulation (Figure 21C). We assume that this substance was released by the male and that it was a type of mating plug, not a spermatophore.

\section{Copulation frequency and time}

Heelwalkers typically exhibited extended copulation times ([20,33]; our observations are summarized in Table 2). However, we do not know exactly when the sperm transfer occurred. Thus, we do not know if the prolonged mating time should be considered as mate guarding and which role prolonged copulation plays in the male and female Mantophasmatodea sexual strategies. Currently, there is no evidence that the copulation time depends on the sexual partners' mating status. Adis et al., [33] reported remating for Mantophasma kudubergense; we observed remating in other species, such as A. gansbaaiense, K. botterkloofense, and Austrophasmatidae sp. n. (S18, Vanrhynsdorp). Remating 24 - $48 \mathrm{~h}$ after the first mating has been observed both with different partners and the same partner, but no partner choice experiments have been conducted. Austrophasmatidae sp. n. (S18, Vanrhynsdorp) males occasionally began drumming $4 \mathrm{~h}$ after mating. In September 2003, in Little Karoo, we observed that $20.8 \%$ of all $H$. montaguense individuals were in copula during the day, which included 10 (i.e., five pairs) out of 48 (25 males, 23 females) individuals.

\section{Mating costs}

In captivity, female heelwalkers in copula were regularly observed hunting and feeding on insects. Therefore, the extra costs from mating may be low for females. In contrast, males do not eat during copula. Thus, males lose a significant amount of weight during copulation. We assume that a short starvation period is a natural phenomenon in Mantophasmatodea, similarly to other carnivorous arthropods (e.g., [69-71]). In addition to starvation and dehydration, transferring substantial amounts of protein and liquids to the females must also be considered. We attempted to assess the costs to males by comparing weight loss during copula versus weight loss during a similar starvation/dehydration period. The weight lost was considered an indicator of the cost to a male during prolonged mating. Weight loss during mating that exceeds a similar starvation period indicates remarkable protein transfer. Therefore, we compared the costs during mating with other biological periods of energy depletion to assess the consequences of prolonged mating for the male energy budget and fitness. In our experiments, Austrophasmatidae sp. n. (S18, Vanrhynsdorp) male weight loss was measured after starvation/dehydration for one group of males (starvation group, $\mathrm{N}=6$ ) and after mating for a 
Table 2 Copulation times for several Mantophasmatodea species in the laboratory

\begin{tabular}{|c|c|c|}
\hline Species & $\begin{array}{l}\text { Observed copulation } \\
\text { times in hours }\end{array}$ & $\begin{array}{l}\text { Number of observed } \\
\text { copulations }\end{array}$ \\
\hline $\begin{array}{l}\text { Karoophasma } \\
\text { botterkloofense (S16) }\end{array}$ & $>29$ & 1 \\
\hline $\begin{array}{l}\text { Karoophasma } \\
\text { botterkloofense }\end{array}$ & 68.5 (S.E. \pm 4.56$)$ & 7 \\
\hline $\begin{array}{l}\text { Austrophasmatidae } \\
\text { sp. n. (S18) }\end{array}$ & $7.5-31.5$ & 17 \\
\hline $\begin{array}{l}\text { Hemilobophasma } \\
\text { montaguense (S26) }\end{array}$ & $20-54$ & 4 \\
\hline $\begin{array}{l}\text { Austrophasma } \\
\text { gansbaaiense (S32) }\end{array}$ & $24^{R}, 24^{R}, 64$ & 3 \\
\hline $\begin{array}{l}\text { Mantophasma spec. } \\
\text { (N21) }\end{array}$ & $18-28$ & 6 \\
\hline $\begin{array}{l}\text { Mantophasma } \\
\text { kudubergense** }\end{array}$ & $12-72$ & 12 \\
\hline $\begin{array}{l}\text { Hemilobophasma sp. } .^{1} \\
\times \text { H. cf. montaguense }{ }^{2}\end{array}$ & $<24$ & 1 \\
\hline $\begin{array}{l}\text { Mantophasmatodea in } \\
\text { general*** }\end{array}$ & Up to 96 & - \\
\hline \multicolumn{3}{|c|}{ 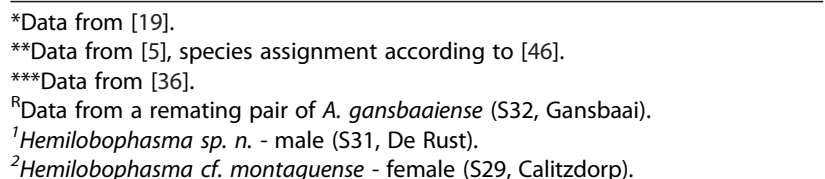 } \\
\hline
\end{tabular}

second group (mating group, $\mathrm{N}=7$ ). Starvation and mating were conducted under the same experimental conditions (temperature $22-24^{\circ} \mathrm{C}, 12 \mathrm{~h}$ light). Preliminary experiments showed 1) that males can lose up to $50 \%$ of their initial body mass within $24 \mathrm{~h}$ of starvation and dehydration, and 2) a significant positive correlation between initial body mass and percent of weight lost was identified (Spearman rank test: $\mathrm{r}=$ $0.89, \mathrm{~N}=10, \mathrm{p}=0.01)$. Therefore, in the following experiments, we only used males with the same body class and feeding status (i.e., both groups did not differ significantly in their average initial weight) (starvation group: 0.033 g, s.d. $0.004 /$ mating group: 0.0325 g, s.d. 0.003; $\mathrm{t}-$ Test: $\mathrm{t}=0.226, \mathrm{df}=11, \mathrm{p}=0.82$ ). Mating was not artificially interrupted, and we assumed copulation with sperm (and protein) transfer in all cases. As a result, the copulation times varied among tested males and were in the 11-21 $\mathrm{h}$ range (average $14.7 \mathrm{~h}$ ), whereas the starvation time was $24 \mathrm{~h}$ for all individuals in the starvation group. The starving males lost body weight in the range of 2.6$29.6 \%$ (average: 13.29, s.d. 11.37), and the males in copulation lost body weight in the range of $3.5-9.0 \%$ (average: 6.38, s.d. 0.81). An analysis of variance confirmed that 1) the initial body weight had a positive effect on the percentage of body weight lost (i.e., the heavier individuals lost relatively more weight), 2) the weight lost between both experimental groups (starving/ desiccating males versus mating males) did not differ, and 3) the treatment time (starvation or copulation time) did not affect the results (Table 3). Altogether, our data show that body weight lost during mating does not differ significantly from loss during a similar starvation and desiccation timeframe. Considering that males do not feed (and most likely do not take in water) during prolonged copulation, the data suggest that proteins are not excessively transferred from males to females.

\section{Conclusions}

Only a few years after the first Mantophasmatodea was described, the literature includes an impressive scientific knowledge on its diversity and biology. In contrast to the well-known distribution range in Southern Africa, however, the Mantophasmatodea range and diversity in East Africa have not been explored as extensively. In addition, the assignments of the known genera to different erected families must be clarified in a thorough revision. Future novel discoveries regarding general aspects of their biology will largely depend on successful breeding in captivity. One particular aspect of their biology is their tendency toward broad species distribution with many local populations. This phenomenon is, in part, due to low dispersal abilities (winglessness, low mobility, and low chance of dispersal for all stages, including eggs). Using mass fingerprints of peptide hormones to map the different populations, it appears possible that intraspecific migration/replacement/hybridization can be followed over a long time period, which is another unique possibility provided by these fascinating insects.

Table 3 Analysis of variance to determine the effects of 1) initial body weight (in g), 2) treatment duration (in hours), and 3) treatments (starvation/desiccating vs. mating) on the percentage of body weight lost in Austrophasmatidae sp. n. males (S18, Vanrhynsdorp)

\begin{tabular}{llllll}
\hline Source of Variation & $\begin{array}{l}\text { Sum of } \\
\text { square }\end{array}$ & DF & $\begin{array}{l}\text { Mean } \\
\text { square }\end{array}$ & F & P \\
\hline Corrected Model & $554.466^{\mathrm{a}}$ & 3 & 184.822 & 5.964 & 0.016 \\
Intercept & 276.439 & 1 & 276.439 & 8.921 & 0.015 \\
Main Effects & & & & & \\
$\quad$ Initial body weight & 385.618 & 1 & 385.618 & 12.444 & 0.006 \\
$\quad$ Duration of treatment & 129.356 & 1 & 129.356 & 4.174 & 0.071 \\
$\quad$ Treatment & 016.256 & 1 & 016.256 & 0.525 & 0.487 \\
$\quad$ Starvation/mating) & 278.885 & 9 & 030.987 & & \\
Error & 2037.005 & 13 & & & \\
Total & 833.351 & 12 & & & \\
Corrected total & & & & & \\
\hline
\end{tabular}

$\mathrm{R}^{2}=0.665$ (adjusted $\mathrm{R}^{2}=0.554$ ). 


\section{Sampling and export permissions}

The insects were captured and exported with permission from the Western and Northern Cape Nature Conservation Boards (no. 2297/2003, 0697/2004, 0554/2004), the Ministry of Environment and Tourism of Namibia (research/collecting permits 891/2005, 1041/2006), and Malawi (Government Document: Department of Forestry Specimens Collection Permit 21/01/2011/no.1).

\section{Additional files}

Additional file 1: Methods.

Additional file 2: Video 1A - Jumping male; Tyrannophasma gladiator. Note: movement of antennae is artificially affected by airflow using a blow-dryer

Additional file 3: Video 1B - Jumping male; Tyrannophasma gladiator. Note: movement of antennae is artificially affected by airflow using a blow-dryer.

Additional file 4: Video 1C - Jumping male; Tyrannophasma gladiator. Note: movement of antennae is artificially affected by airflow using a blow-dryer.

Additional file 5: Video 1D- Female is jumping over a male which tries to mount and copulate afterwards; Karoophasma botterkloofense.

Additional file 6: Video 2A- Flexible body whilst jumping; Tyrannophasma gladiator.

Additional file 7: Video 2B- Flexible body whilst jumping; Tyrannophasma gladiator.

Additional file 8: Video 3A - Landing behavior after dropping; Tyrannophasma gladiator.

Additional file 9: Video 3B - Landing behavior after dropping; Tyrannophasma gladiator.

Additional file 10: Video 4 - Grooming behavior; Austrophasmatidae sp. nov. (S18, Vanrhynsdorp).

Additional file 11: Video 5 - Antenna-flickering, Austrophasmatidae sp. nov. (S18, Vanrhynsdorp).

Additional file 12: Video 6A - Foraging behavior; Karoophasma botterkloofense.

Additional file 13: Video 6B - Foraging behavior; Austrophasmatidae sp. nov. (S18, Vanrhynsdorp).

Additional file 14: Video $6 \mathrm{C}$ - Foraging behavior; Austrophasmatidae sp. nov. (S18, Vanrhynsdorp).

Additional file 15: Video 6D - Foraging behavior; Austrophasmatidae sp. nov. (S18, Vanrhynsdorp).

Additional file 16: Video 7 - Foraging behavior (details);

Pachyphasma brandbergense.

Additional file 17: Video 8a, Drumming behavior; Austrophasmatidae sp. nov. (S18, Vanrhynsdorp).

Additional file 18: Video 8B - Drumming behavior; Austrophasmatidae sp. nov. (S18, Vanrhynsdorp).

Additional file 19: Video 9B - Mating behavior; Austrophasmatidae sp. nov. (S18, Vanrhynsdorp).

Additional file 20: Video 10 - Female foraging whilst in copula; Austrophasmatidae sp. nov. (S18, Vanrhynsdorp).

Additional file 21: Video 11 - Female defense against male; Austrophasmatidae sp. nov. (S18, Vanrhynsdorp).
Authors' contributions

SR and RP conducted field samplings and observations. Rearing, laboratory observations including video and vibrational signal tapping were performed by RP and partly by SR. The mating cost experiment was carried out and analyzed by SR. JM analyzed the vibrational signals. Data interpretation and preparation of the manuscript was done by SR, RP and JM. The final manuscript was written by RP and SR. All authors read, commented on and approved the final manuscript.

\section{Acknowledgments}

We wish to thank the following individuals for support during the numerous field trips and for their help in the laboratory work with Mantophasmatodea: Susanne Neupert (Köln), Wolf Hütteroth (Konstanz), Mike Picker (Cape Town), Adrian Scheidt (Groningen), Martin Scheidt (Vienna), Moritz and Marie Predel (Jena), Rene Köhler (Köln), Alexander König (Göttingen), Udo Neugebauer (Saalburg), Thomas Schmalenberg (Leipzig), Holger Vollbrecht (Windhoek), Martin Fischer (Jena) and Benson Muramba (Windhoek). We thank Louis Boumans (Oslo) for useful comments on our vibrational studies. We also acknowledge comments from Mike Picker on a former version of the manuscript and Dirk U. Bellstedt (Stellenbosch) for plant determination. This study was supported by travel grants from the Boehringer Ingelheim Stiftung, the British Ecological Society, and the Orthoperists' Society of America. Remains of orbatids in intestines were confirmed by Torstein Solhøy, Roy A. Norton, and Arne Fjellberg (Bergen; in litt.).

\section{Author details}

${ }^{1}$ University Museum of Bergen, The Natural History Collections, P.O. Box 7800, N-5020 Bergen, Norway. ${ }^{2}$ Departamento de Ciencias Biologicas, Universidad de Los Andes, Apartado Aerea 4976, Bogota, Colombia. ${ }^{3}$ University of Cologne, Institute for Zoology, Zuelpicher Str. 47b, 50674 Cologne, Germany.

Received: 8 August 2014 Accepted: 18 September 2014

Published online: 10 October 2014

References

1. Klass K-D, Zompro O, Kristensen NP, Adis J: Mantophasmatodea: A new insect order with extant members in the Afrotropics. Science 2002, 296:1456-1459.

2. Picker MD, Colville JF, van Noort S: Mantophasmatodea, Now in South Africa. Science 2002, 297:1475.

3. Walker EM: A new species of Orthoptera, forming a new genus and new family. Can Entomologist 1914, 45:93-99.

4. Klass K-D, Picker MD, Damgaard J, van Noort S, Tojo K: The taxonomy, genitalic morphology, and phylogentic relationships of southern African Mantophasmatodea (Insecta). Entomologische Abhandlungen 2003, 61:3-67.

5. Zompro O, Adis J, Bragg PE, Naskrecki P, Meakin K, Wittneben M, Saxe V: A new genus and species of Mantophasmatidae. Insecta: Mantophasmatodea) from Brandberg Massif, Namibia, with notes on behaviour. Cimbebasia 2003, 19:13-24.

6. Zompro O: Inter- and intra-ordinal relationships of the Matophasmatodea, with comments on the phylogeny of polyneopteran orders (Insecta: Polyneoptera). Mitteilungen des Geologisch 2005, 89:85-114

7. Dallai R, Frati F, Lupetti P, Adis J: Sperm ultrastructure of Mantophasma zephyra (Insecta, Mantophasmatodea). Zoomorphology 2003, 122:67-76.

8. Tsutsumi T, Machida R, Tojo K, Uchifune T, Klass KD, Picker MD: Transmission electron microscopic observations of the egg membranes of a South African heel-walker Karoophasma biedouwensis (Insecta: Mantophasmatodea). Proc Arthropodan Embryol Soc Jpn 2004, 39:23-29.

9. Uchifune T, Machida R, Tsutsumi T, Tojo K: Chorion of a South African heel-walker, Karoophasma biedouwensis Klass et al. SEM observations (Insecta: Mantophasmatodea). Proc Arthropodan Embryol Soc Jpn 2006, 41:29-35.

10. Baum E, Dressler C, Beutel RG: Head structures of Karoophasma sp. (Hexapoda, Mantophasmatodea) with phylogenetic implications. J Zool Syst Evol Res 2007, 45:104-119.

11. Klass K-D, Eulitz U: The tentorium and anterior head sulci in Dictyoptera and Mantophasmatodea (Insecta). Zool Anz 2007, 246:205-234.

12. Pass G, Gereben-Krenn B-A, Merl M, Plant J, Szucsich NU, Tögel M: Phylogenetic relationships of the orders of Hexapoda: contributions from 
the circulatory organs for a morphological data matrix. Arthropod Syst Phylogeny 2006, 64:165-203.

13. Beutel RG, Gorb SN: A revised interpretation of the evolution of attachment structures in Hexapoda with special emphasis on Mantophasmatodea. Arthropod Syst Phylogeny 2006, 64:3-25.

14. Beutel RG, Gorb SN: Evolutionary scenarios for unusual attachment devices of Phasmatodea and Mantophasmatodea (Insecta). Syst Entomol 2008, 33:501-510.

15. Eberhard MJB, Pass G, Picker MD, Beutel R, Predel R, Gorb SN: Structure and function of the Arolium of Mantophasmatodea (Insecta). J Morphol 2009, 270:1247-1261.

16. Buder G, Klass K-D: The morphology of tarsal processes in Mantophasmatodea. Deutsche Entomologische Zeitschrift 2013, 60:5-23.

17. Hockman D, Picker MD, Klass K-D, Pretorius L: Postembryonic development of the unique antenna of Mantophasmatodea (Insecta). Arthropod Struct Dev 2009, 38:125-133.

18. Drilling K, Klass KD: Surface structures of the antenna of Mantophasmatodea (Insecta). Zool Anz 2010, 249:121-137.

19. Tojo K, Machida R, Klass K-D, Picker MD: Biology of South African heel-walkers, with special reference to reproductive biology (Insecta: Mantophasmatodea). Proc Arthropodan Embryol Soc Jpn 2004, 39:15-21.

20. Eberhard MJB, Picker MD: Vibrational communication in two sympatric species of Mantophasmatodea (Heelwalkers). J Insect Behav 2008, 2008 (21):240-257.

21. Eberhard MJB, Lang D, Metscher B, Pass G, Picker MD, Wolf H: Structure and sensory physiology of the leg scolopidial organs in Mantophasmatodea and their role in vibrational communication. Arthropod Struct Dev 2010, 39:230-241.

22. Eberhard MJB, Eberhard SH: Evolution and Diversity of Vibrational Signals in Mantophasmatodea (Insecta). J Insect Behav 2012, 26:352-370.

23. Predel R, Roth S, Neupert S, Picker M: New insect order Mantophasmatodea: Species differentiation by mass fingerprints of peptide hormones? J Zool Syst Evol Res 2005, 43:149-156.

24. Gäde G, Marco HG, Simek P, Marais E: The newly discovered insect order Mantophasmatodea contains a novel member of the adipokenetic hormone family of peptides. Biochem Biophys Res Commun 2005, 330:598-603.

25. Chown SL, Marais E, Picker MD, Terblanche JS: Gas exchange characteristics, metabolic rate and water loss of the Heelwalker, Karoophasma biedouwensis (Mantophasmatodea: Austrophasmatidae). J Insect Physiol 2006, 52:442-449.

26. Machida R, Tojo K, Tsutsumi T, Uchifune T, Klass KD, Picker MD, Pretorius $L$ : Embryonic development of heel-walkers: Reference to some preevolutionary stages (Insecta: Mantophasmatodea). Proc Arthropodan Embryol Soc Jpn 2004, 39:31-39.

27. Tsutsumi T, Tojo K, Uchifune T, Machida R: Ovarian structure and oogenesis of the South African heel-walker Karoophasma biedouwensis (Insecta: Mantophasmatodea). Proc Arthropodan Embryol Soc Jpn 2005, 40:15-22.

28. Cameron SL, Barker SC, Whiting MF: Mitochondrial genomics and the new insect order Mantophasmatodea. Mol Phylogenet Evol 2006, 38:274-279.

29. Terry MT, Whiting MF: Mantophasmatodea and phylogeny of the lower neopterous insects. Cladistics 2005, 21:240-257.

30. Damgaard J, Klass K-D, Picker MD, Buder G: Phylogeny of the Heelwalkers (Insecta: Mantophasmatodea) based on mtDNA sequences, with evidence for additional taxa in South Africa. Mol Phylogenet Evol 2008, 47:443-462.

31. Predel R, Neupert S, Huetteroth W, Kahnt J, Waidelich D, Roth S: Peptidomics-based phylogeny and biogeography of Mantophasmatodea (Hexapoda). Syst Biol 2012, 61:609-629.

32. Kjer KM, Carle FL, Litman J, Ware J: A molecular phylogeny of Hexapoda. Arthropod Systematics \& Phylogeny 2006, 2006(64):35-44.

33. Adis J, Marais E, Moombolah-Goagoses E, Zompro O: Gladiatoren: Gespenstische Räuber. Spektrum Wissensch 2003, 2003:64-69.

34. Walker JA: Mantophasmatodea - a new order of insects. Bull Amateur Entomologists' Soc 2003, 62:72-78.

35. Zompro O: Mantophasmatodea - Gladiatoren im Insektenreich. Arthropoda 2008, 16:4-25.

36. Klass K-D: Mantophasmatodea, Die zuletzt entdeckte Insektenordnung. Nat Mus 2009, 139:218-227.
37. Adis J, Zompro O: Gladiators: A new order of Insects. Sci Am 2002, 287:60-67.

38. Zompro O, Adis J, Weitschat W: A review of the order Mantophasmatodea (Insecta). Zoologischer Anzeiger 2002, 241:269-279.

39. Arillo A, Engel MS: Rock Crawlers in Baltic Amber (Notoptera: Mantophasmatodea). Am Mus Novit 2006, 3539:1-10.

40. Machida R, Tojo K: Heel walkers, a new insect order Mantophasmatodea. (In Japanese). Kontyu to Shizen 2003, 38:26-31.

41. Picker M, Griffiths C, Weaving A: Field guide to insects of South Africa. Cape Town: Struik Publishers; 2004

42. Huang DY, Nel A, Zompro O, Waller A: Mantophasmatodea now in the Jurassic. Naturwissenschaften 2008, 10:947-952.

43. Arillo A, Ortuno VM, Nel A: Description of an enigmatic insect from Baltic amber. Bulletin de la Société entomologique de France 1997, 102:11-14.

44. Eberhard MJB, Picker MD, Klass K-D: Sympatry in Mantophasmatodea, with the description of a new species and phylogenetic considerations. Organisms Diversity \& Evolution 2011, 11:43-59.

45. Wipfler B, Pohl H, Predel R: Two new genera and species of Mantophasmatodea (Insecta, Polyneoptera) from Namibia. Zookeys 2012, 166:75-98.

46. Zompro O, Adis J: Notes on Namibian Mantophasma Zombro, Klass Kristensen \& Adis 2002, with descriptions of three new species (Insecta: Mantophasmatodea: Mantophasmatidae: Mantophasmatini). Russ Entomol J 2006, 15:21-24.

47. Mloza-Banda HR: Development and application of conservation agriculture in Malawi's smallholder subsistence and commercial farming systems. In Proceedings of Workshop on Conservation Farming for Sustainable Agriculture: 20-24 October 2002. Edited by Mloza-Banda HR, Kumwenda WF, Manda M, Bwalya M. Lilongwe, Malawi: Land Resources Conservation Department; 2003

48. Williams J: Adoption of conservation agriculture in Malawi. In Master thesis. Durham, North Carolina: Nicholas School of Environment of Duke University; 2008.

49. Holm E: Notes on faunas bordering on the Namib Desert. In Namib Ecology: 25 years of Namib Research. Edited by Seely MK. Pretoria: Transvaal Museum Monographs; 1990:55-60.

50. Jürgens N: Floristic biodiversity and history of African arid regions. Biodivers Conserv 1997, 6:495-514

51. Partridge TC: Evolution of landscapes. In Vegetation of Southern Africa. Edited by Cowling RM, Richardson DM, Pierce SM. Cambridge: Cambridge University Press Cambridge; 1997:5-20.

52. Haughton SH: Geological history of Southern Africa. The Geological Society of South Africa: Cape Town; 1969.

53. Simmons RE, Griffin M, Griffin RE, Marais E, Kolberg H: Endemism in Namibia: patterns, processes and predictions. Biodivers Conserv 1989, 7:513-530.

54. Redman GT, Hamer ML: The distribution of southern African Harpagophoridae Attems, 1909 (Diplopoda: Spirostreptida). Afr Invertebr 2003, 44:213-226.

55. Kirk-Spriggs AH, Marais E: Dâures-biodiversity of the Brandberg Massif. Namibia Cimbebasia Memoir 2000, 9:1-389.

56. Cowling R: The ecology of Fynbos. Nutrition, fire and diversity. Cape Town: Oxford University Press; 1992

57. Lovegrove B: The living deserts of Southern Africa. Vlaeberg: Fernwood Press; 1993.

58. Picker MD, Samways MJ: Faunal diversity and endemicity of the Cape Peninsula, South Africa-a first assessment. Biodiversity \& Conservation 1996, 5:591-606

59. Huber BA, Sinclair BJ, Lampe K-H (Eds): African Biodiversity: Molecules, Organisms, Ecosystems. Proceedings of the 5th International Symposium on Tropical Biology, Museum Alexander Koenig, Bonn. New York: Springer; 2005.

60. Craven P, Craven D: The flora of the Brandberg, Namibia. Cimbebasia Memoir 2000, 9:49-67.

61. Myers N, Mittermeier RA, Mittermeier CG, da Fonseca GA, Kent J: Biodiversity hotspots for conservation priorities. Nature 2000, 403:853-858.

62. Wipfler B: Mantophasmatodea. In Insect Morphology and Phylogeny. Edited by Beutel RG, Friedrich F, Ge S-Q, Yang X-K. Berlin: De Gruyter; 2014:272-277.

63. Cukier M, Guerrero GA, Maggese MC: Parthenogenesis in Coptopteryx viridis, Giglio Tos (1915) (Dyctioptera, Mantidae). Biol Bull 1979, 157:445-452. 
64. Uchifune T: Collection and rearing of a South African heel-walker, Karoophasma biedouwensis Klass et al. (Insecta: Mantophasmatodea). Science Report of the Yokosuka City Museum 2008, 55:23-28.

65. Power JH: On the biology of Acanthoplus bechuanus Per (Orthoptera: Tettigoniidae). J Entomological Soc South Africa 1958, 21:376-381.

66. New TR: Insects as predators. Sydney: New South Wales University Press; 1991.

67. Reinhold K: Variation of acoustic courtship signals in insects and amphibians: No evidence for bimodality, but identical dependence on duration. Ethology 2009, 115:131-140.

68. Rupprecht R: Drumming signals of Danish Plecoptera. Aquat Insects 1992 4:93-103.

69. Dixon AFG, Russel RJ: The effectiveness of Anthocoris nemorum and $A$. confusus (Hemiptera: Anthocoridae) as predators of the sycamore aphid, Drepanophisum platanoides. Entomologia Experimentales et Applicata 1972, 13:194-207.

70. Wise DH: Spiders in ecological webs. Cambridge: University Press; 1993.

71. Moran MD, Hurd LE: Relieving food limitations reduces survivorship of a generalist predator. Ecology 1997, 78:1266-1270.

doi:10.1186/s12983-014-0070-0

Cite this article as: Roth et al.: Biodiversity, ecology, and behavior of the recently discovered insect order Mantophasmatodea. Frontiers in Zoology 2014 11:70.

\section{Submit your next manuscript to BioMed Central and take full advantage of:}

- Convenient online submission

- Thorough peer review

- No space constraints or color figure charges

- Immediate publication on acceptance

- Inclusion in PubMed, CAS, Scopus and Google Scholar

- Research which is freely available for redistribution 